Southern Methodist University

SMU Scholar

Sociology Research

Sociology

$9-2005$

\title{
Pathways to Power: The Role of Political Parties in Women's National Political Representation
}

\author{
Sheri L. Kunovich \\ Southern Methodist University, kunovich@smu.edu \\ Pamela Paxton \\ Ohio State University - Main Campus, paxton.36@osu.edu
}

Follow this and additional works at: https://scholar.smu.edu/hum_sci_sociology_research

Part of the Comparative Politics Commons, Gender and Sexuality Commons, Politics and Social Change Commons, Quantitative, Qualitative, Comparative, and Historical Methodologies Commons, and the Sociology of Culture Commons

\section{Recommended Citation}

Kunovich, Sheri, and Pamela Paxton. 2005. "Pathways to Power: The Role of Political Parties in Women's National Political Representation." American Journal Of Sociology 111, no. 2: 505-552.

This document is brought to you for free and open access by the Sociology at SMU Scholar. It has been accepted for inclusion in Sociology Research by an authorized administrator of SMU Scholar. For more information, please visit http://digitalrepository.smu.edu. 
Southern Methodist University

SMU Digital Repository

Sociology Research

Sociology

9-1-2005

\section{Pathways to Power: The Role of Political Parties in Women's National Political Representation}

Sheri L. Kunovich

Pamela Paxton

This document is brought to you for free and open access by the Sociology at SMU Digital Repository. It has been accepted for inclusion in Sociology

Research by an authorized administrator of SMU Digital Repository. For more information, please contact robertw@mail.smu.edu,

cholloway@mail.smu.edu. 


\title{
Pathways to Power: The Role of Political Parties in Women's National Political Representation ${ }^{1}$
}

\author{
Sheri Kunovich \\ Southern Methodist University \\ Pamela Paxton \\ Ohio State University
}

\begin{abstract}
The authors extend previous research on women's participation in politics by examining the role of female elites in political parties in selecting and supporting women as political candidates. They hypothesize that political parties, in their role as gatekeepers, mediate the relationship between country-level factors, such as women's participation in the labor force, and political outcomes for women. The article focuses on three outcomes for women: the percentage of female political party leaders, the percentage of female candidates in a country, and the percentage of women elected. New cross-national measures of women's inclusion in political parties are developed and analyzed in a cross-national, path-analytic model of women in politics to find that (1) women's position in party elites translates into gains for women as candidates only under proportional representation systems, (2) women's position in party elites increases the likelihood that female candidates will be elected only in nonproportional representation systems, and (3) parties may be overly sensitive to the perceived liability of women as candidates, when in fact, women have success as candidates across all regions of the world.
\end{abstract}

Women's representation in formal politics matters both normatively and practically. From a normative standpoint, political elites should represent the interests of all citizens, including traditionally marginalized groups

\footnotetext{
${ }^{1}$ As authors, we contributed equally to this article. We thank Paul von Hippel, Robert Kunovich, Melanie Hughes, Jennifer Green, Lindsey Peterson, Katherine Meyer, Kira Sanbonmatsu, and the $A J S$ reviewers for helpful comments on an earlier draft of this paper. Direct correspondence to Sheri Kunovich, Department of Sociology, Southern Methodist University, Campus Box 750192, Dallas, Texas 75275. E-mail: kunovich@smu.edu, paxton.36@osu.edu
}

(C) 2005 by The University of Chicago. All rights reserved.

0002-9602/2005/11102-0004\$10.00 
such as women (Williams 1998; Phillips 1991). Practically, a lack of female participation can result in a state that legislates in the male interest (MacKinnon 1989; Connell 1990; Waylen 1994). In that case, society-wide decisions in the form of legislation and the allocation of resources may not be enacted in women's interests. In addition, political position carries highly visible status and prestige. While women have made remarkable inroads into both tertiary education and traditionally male occupations, the political sphere remains an arena in which women have not yet gained comparably visible status. Women are highly underrepresented in national politics, with the average percentage of women in parliaments only $15.2 \%$ as of January 2004 (IPU 2004). To understand the overall position of women within society it is therefore necessary to examine women's underrepresentation within the political structure.

The quantitative literature on women's presence in legislatures can generally be classified into two approaches. The first approach focuses on national-level patterns of women's parliamentary representation. In this approach, country-level variables are used to explain variation in the percentage of women in national legislatures across countries (Kenworthy and Malami 1999; Paxton 1997; Paxton and Kunovich 2003; Matland 1998; Reynolds 1999). For example, the percentage of women in the labor force of a country is hypothesized to represent the "supply" of women available for public office and therefore increase numbers of women in parliament (e.g., Paxton 1997). These studies tend to be large- $N$, crossnational, statistical studies with the goal of explaining variation across countries.

A second approach focuses instead on party-level differences in the representation of women. This research has asked why parties differ with respect to the number of women they nominate as candidates, where those parties rank women on party lists, and the proportion of women they send to parliaments (Caul 1999; Gallagher and Marsh 1988; Kunovich 2003; Matland and Studlar 1996; Tremblay and Pelletier 2001; Sanbonmatsu 2002; Mateo Diez 2002; Welch and Studlar 1996). For example, leftist parties are hypothesized to provide greater support to women's candidacies because they espouse egalitarian ideologies (e.g., Caul 1999; Beckwith 1992). Similarly, parties with women in positions of power are hypothesized to positively affect the adoption of measures favoring female candidates (e.g., Tremblay and Pelletier 2001). Because the focus is on very detailed information about parties, these studies tend to focus within particular countries, or a small number of countries, across a range of parties.

In this article, we try to advance understanding of the overall process by which women are elected to national political office in two ways. First, we combine the two approaches outlined above, focusing on the ways in 
which political parties mediate and interact with the effects of countrylevel variables in producing political outcomes for women. Second, we focus on multiple points of contact for women in the political system, arguing that to understand women in the overall process of politics, it is important to understand women's inclusion in parties, women as candidates, and women as elected officials.

We view the electoral process as creating two "filter" points for women. In passing through the first filter, women must be selected by parties in order to run for political office. In passing through the second, women must be selected by the electorate in order to achieve political office. We model both filters, hypothesizing that country-level and party-level factors should influence both the number of female candidates and how well those female candidates translate into female legislators.

Our study is cross-national in that we consider a large number of countries. This allows us to consider the country-level variables found to be important in so much previous research. At the same time, we include information about the inclusion of women in the political parties of each country. We hypothesize that, in their role as gatekeepers, political parties mediate and interact with the effects of the country-level factors in producing political outcomes for women. For example, some parties may have elites who are disposed to field female candidates, regardless of country-level pressures. Yet, it is likely that political parties are themselves strongly influenced by country-level factors. For example, parties operating under a proportional representation electoral system may feel pressured to balance male and female candidates on their party lists, regardless of their leaders' views on women (Matland and Studlar 1996). Interaction effects are also possible: party elites favorable to women may have an easier time influencing the number of female candidates in proportional representation systems compared to other systems.

Overall, our model of women in politics uses both country- and partylevel characteristics to look at three sequential outcomes: women's inclusion in party elites, the percentage of female candidates fielded by the parties of a country, and the percentage of women elected to the national legislature. We also model the yield of female legislators from candidates to assess whether the "return" on female candidates varies across countries. We hypothesize that some or all of the effect of country-level variables operates through their effect on political parties and those parties' decisions to field and support female candidates. To our knowledge, this is the first empirical study to consider multiple points of contact for women in the political system. In addition, it is the first study to consider countrylevel and party-level influences simultaneously across a wide variety of 
American Journal of Sociology

countries. ${ }^{2}$ The process of election is complex and necessitates a model that accounts for this complexity.

We complement our quantitative analyses with qualitative information from case studies (e.g. Young 2000; Goetz and Hassim 2003) and a recently released international survey of women in politics (IPU 2000). Case studies provide rich detail documenting the internal operations and negotiations within political parties. The Inter-Parliamentary Union (IPU) survey of women in politics final report chronicles interviews with over 200 female politicians (IPU 2000). Including illustrative qualitative information from the case studies and the survey helps us corroborate our claims and adds depth to our statistical findings. Overall, our findings have important implications for policies directed at increasing the number of women in politics.

\section{WOMEN AS CANDIDATES, WOMEN AS ELECTED OFFICIALS}

Understanding women's participation in politics begins by acknowledging that in no country do women make up 50\% of the national legislature. Regardless, there is a great deal of variation across countries, from less than 5\% in countries such as Egypt, to over $40 \%$ in some Scandinavian and African countries. On average, women were $9.5 \%$ of national legislatures worldwide in 1995, the year of this analysis.

Political parties also vary substantially in the proportion of women they field as candidates, and, therefore, in the proportion of women they may send to parliament. Across the 460 political parties in 76 countries used in this analysis, women were $15 \%$ of candidates. Some parties fielded no female candidates, while others (generally women's parties) fielded $100 \%$ women. Table 1 records information on the percentage of female candidates, percentage of female members of the national legislature, and the ratio of the two.

An initial manipulation of the numbers in table 1 reveals two important insights:

\footnotetext{
${ }^{2}$ In her 1997 edited volume, Norris develops a theoretical model of recruitment that is used by others to understand the candidate selection process in a variety of individual country studies. However, the model is not consistently tested across the studies (see also Matland and Montgomery 2003; Norris 1996; and Rule 1981). Caul (1999) tests the effects of party characteristics on women's electoral outcomes, but with data for only 12 advanced industrial nations, she is unable to include any country-level predictors except proportional representation system. In our opinion, the lack of crossnational research focusing on process results primarily from a lack of data rather than a lack of interest. To our knowledge, the IPU data that we use in this article are the first such comprehensive information on parties and candidates available crossnationally.
} 
1. The relationship between the percentage of female candidates fielded by parties and the percentage of female legislators elected is tight - the percentage of female candidates explains nearly $70 \%$ of the variance in the percentage of females in national legislatures.

2. For a $1 \%$ increase in the number of female candidates, there is only a $.67 \%$ increase in female legislators. Thus, the "return" on female candidates is low. ${ }^{3}$

The first insight suggests that to understand female legislators, we must first understand female candidates. The second insight suggests that understanding candidates is not enough-we must also understand the factors that enhance or inhibit the translation of female candidates into female legislators.

The strong relationship between female candidates and female elected officials is the result of the political process of election. In most countries, the recruitment and selection of political elites occurs entirely within political parties (Norris 1993; Gallagher and Marsh 1988). Indeed, candidate selection is viewed as an essential function of political parties (Bille 2001; Gallagher and Marsh 1988; Rahat and Hazan 2001). Therefore, in order for an individual, man or woman, to run for political office, he or she must be selected and supported by a political party. In this way, partyspecific decisions about fielding candidates lead to the countrywide representation of women as candidates.

Relatively little is known about candidate selection methods because it is a power few party elites want to share with the general membership. As explained by Pesonen (1968, p. 348), "The nomination stage eliminates $99.96 \%$ of all the eligible people; the voters choose from only .04\%." Unlike the primary system in the United States, candidate selection is not open for public inspection and participation in most other nations. For example, both the Conservative and Liberal Democratic parties in Britain generate a list of centrally approved candidates that local constituency members use in selecting candidates (British Broadcasting Corporation News 2001). Access to the political elite is "controlled by a series of 'gatekeepers,' and the narrowest gate of all is that guarded by the candidate selectors" (Gallagher and Marsh 1988, p. 2).

\footnotetext{
${ }^{3}$ In fact, the return is even lower if other important variables are controlled, as shown in table 3 below. In table 1, with the exception of four countries (the Netherlands, Mexico, Grenada, and Seychelles), the percentage of women in the national legislature is never more than $5 \%$ higher than the percentage of female candidates. On the other hand, there are numerous examples where the percentage of women in the legislature is substantially lower than the percentage of female candidates. For example, in Iceland, women are $50 \%$ of candidates and $25 \%$ of representatives.
} 


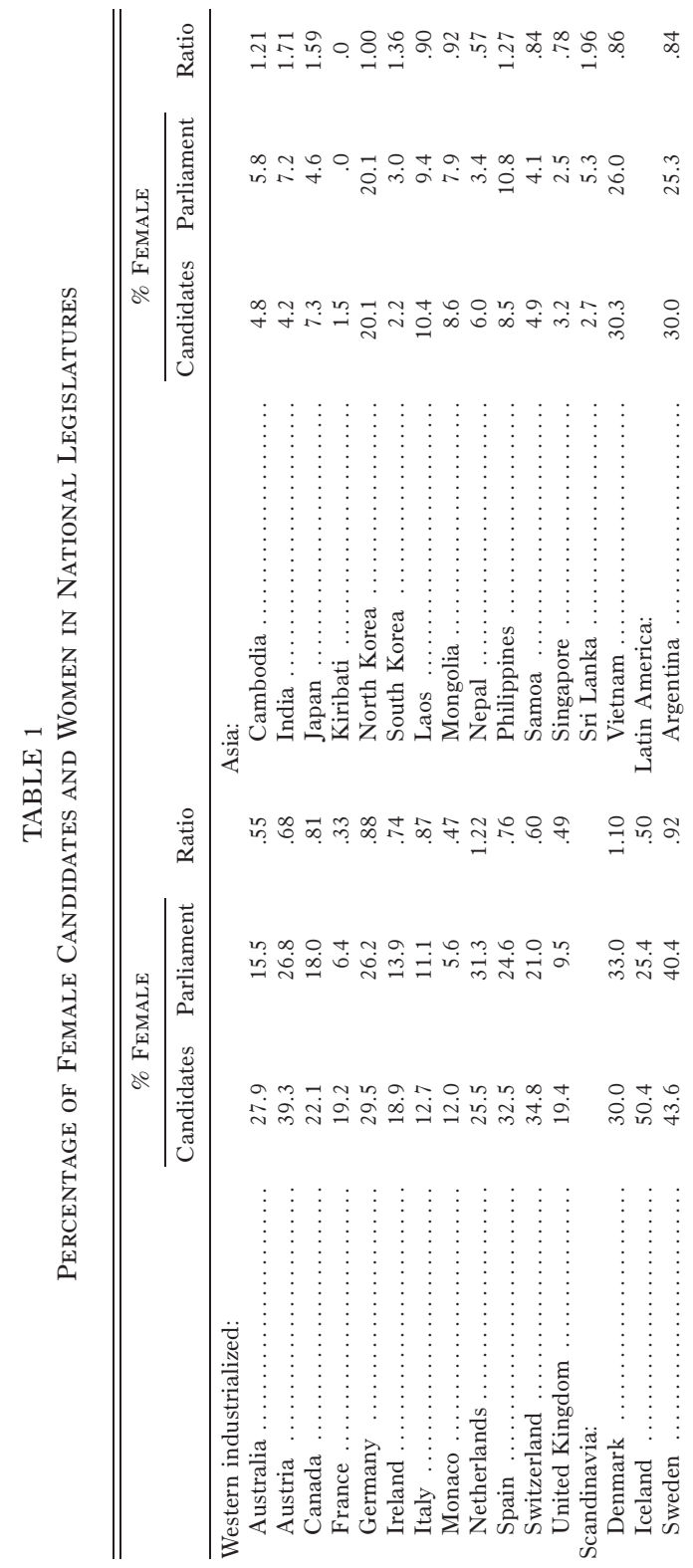




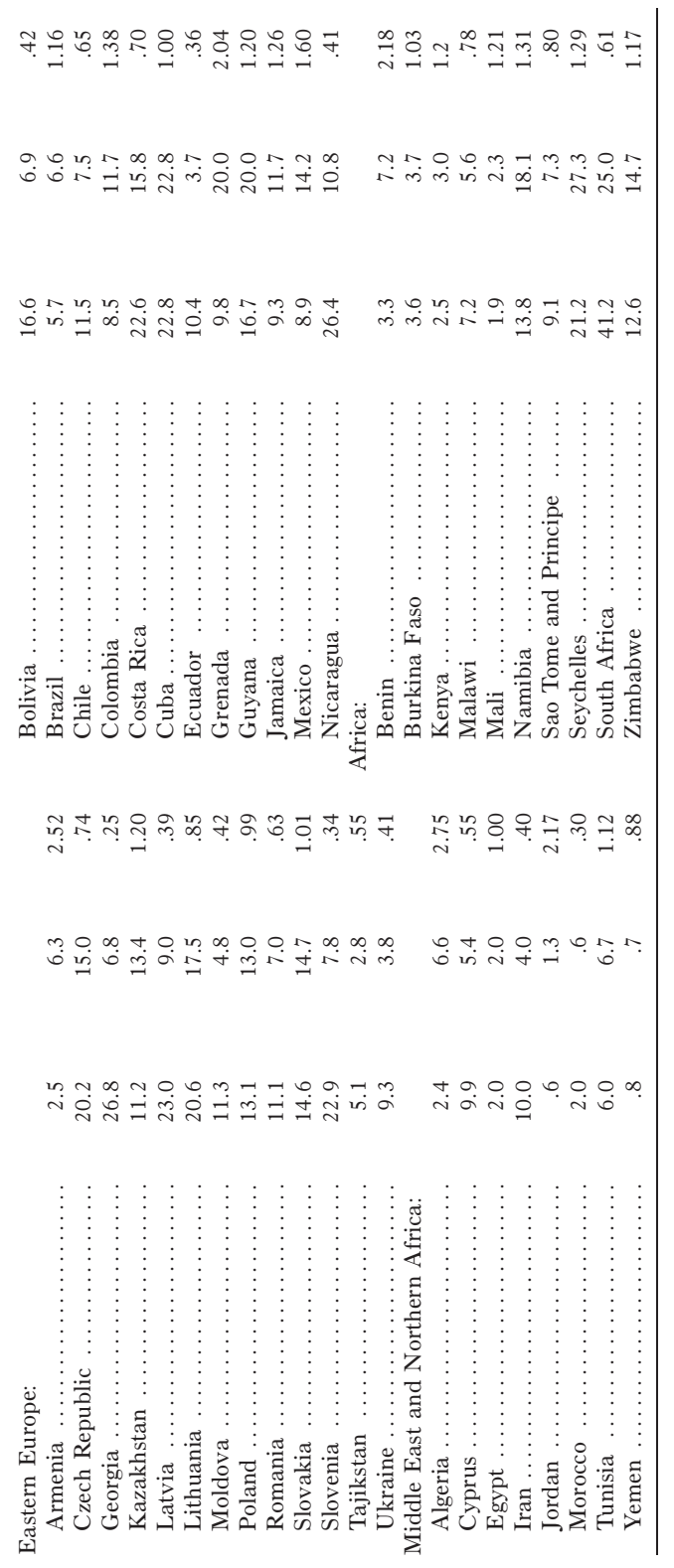


American Journal of Sociology

Once selected, parties are the major source of support for candidates in their bid for public office. Parties in proportional representation systems can support candidates by placing them in favorable list positions, while parties in plurality-majority systems can improve a candidate's chances of election by providing additional financial and institutional resources for campaigning. Previous research has documented that under proportional representation systems women are less likely than men to be placed in "safe" list positions or in open districts where their likelihood of electoral success would be higher (Kunovich 2003).

The role of parties in the selection and support of candidates looms large across single- and multiparty systems, and across full democracies, transitional democracies, and even authoritarian regimes (Abukhalil 1997; Gallagher and Marsh 1988). The process of candidate selection may vary across different contexts according to how centralized the process is, how extensive participation of party members is, and the degree to which objective or subjective characteristics of the aspirants matter for selection (Gallagher and Marsh 1988; Bille 2001; Rahat and Hazan 2001). But it is always parties that control the process. Even under the most tightly controlled political system there is still competition among aspirants for seats in the national legislature, and political parties are generally the institutions within which the struggle occurs.

Thus, while the sentiments of the electorate and the nature of the regime in power are obviously important in getting candidates elected, parties play a crucial role as well. Understanding the relationship between certain party characteristics and political outcomes for women is a major goal of this paper.

\section{A MODEL OF WOMEN IN POLITICS}

Figure 1 presents a general theoretical model of women in politics. We view the inclusion of women in politics as a process with three visible sequential outcomes. Briefly, country-level factors, such as the percentage of women in the labor force and whether a country has a proportional representation system, directly influence all outcomes of interest: women's inclusion in party elites, the percentage of women fielded as candidates across all political parties, and the percentage of women elected. Women party elites can influence the percentage of women fielded as candidates, and both the presence of women in elite party circles and the number of women who run influence how many women actually attain a legislative position. It is also important to note that country-level factors and women party elites should also influence how well female candidates translate into female legislators, or the "return" on female candidates. The yield of 


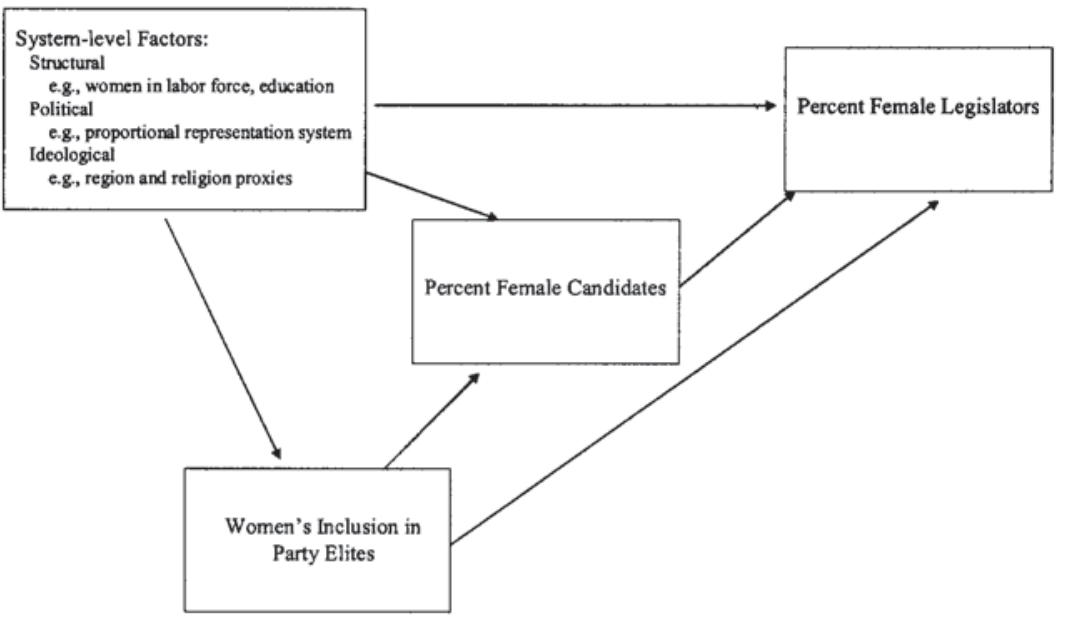

FIG. 1.-The process of women's inclusion in politics

legislators from candidates is captured by the ratio of female legislators to female candidates. In what follows, we explain this process in more detail.

\section{National-Level Explanations}

Cross-national research on women in national legislatures has identified three country-level factors that influence the percentage of women in parliaments: structural, political, and ideological. Although the focus in previous theoretical work has typically been on women's national legislative representation, the arguments are transferable to other political outcomes of importance to women.

First, structural explanations predict that women's educational achievements and women's participation in the labor force will positively affect women's levels of representation. Based in the observation that political elites are pulled disproportionately from the highly educated and from certain professions such as law (Putnam 1976), structural explanations argue that women need human and financial capital (gained through educational and work experience) to stand for office. It follows that the percentage of women who are economically active and who are highly educated should influence political outcomes for women, such as the percentage of female candidates in a country. ${ }^{4}$

\footnotetext{
${ }^{4}$ Empirical evidence for the impact of structural variables on women's national legislative participation is mixed (Kenworthy and Malami 1999; Norris 1985; Paxton
} 
American Journal of Sociology

Qualitative evidence supports the importance of structural factors. As a respondent from Southeast Asia in the IPU survey explains, "Educated women (tertiary level) and professionals in their mid-thirties onwards . . . form a pool from which candidates would be selected" (IPU 2000, pp. 96-97). The importance of a growing pool of qualified candidates is one explanation for the dramatic increases in women's representation in several African legislatures in recent years (Tripp 2001). Considering figure 1 , at each point in the political process of election, the "supply" of available women (those with the requisite human and financial capital) should impact the number of women who make it through each filter.

In contrast to the "supply" of women, political explanations stress that political systems may have different "demands" for female candidates. Political and electoral systems either enhance or limit the ability of men, women, and other groups in government to promote their own interests and can be crucial factors in allowing women access in equal numbers (Caul 1999, 2001; Matland 1998; Giele and Smock 1977; Kohn 1980). Thus, system-level political factors, such as whether the country is a democracy or whether it has a proportional representation electoral system, are important in understanding the number of women in national legislatures.

For example, it is generally accepted that the presence of a proportional representation system, rather than a plurality-majority system (e.g., as in the United States), aids women in gaining access to the political system (Lovenduski and Hills 1981; Norris 1985; Rule 1987; Kenworthy and Malami 1999; Matland 1998). Proportional representation systems attempt to correlate the number of seats won by a political party with the number of votes cast for that party. In a proportional representation system, if a party wins $30 \%$ of the votes, they receive $30 \%$ of the parliamentary seats. In proportional representation closed-list systems, citizens vote for party lists of candidates rather than individual candidates. If a party won $30 \%$ of seats, legislators would be selected by moving down the party list, in order, until all seats were filled. This type of system almost always makes

1997). Several researchers have included a measure of women's educational attainment to predict women's representation (Kenworthy and Malami 1999; Moore and Shackman 1996; Paxton 1997; Rule 1981, 1987). However, with the exception of Rule (1981), no cross-national study has found a statistically significant effect. This is most likely because data limitations have prevented researchers from measuring women's achievements in particular fields such as law, which should more accurately predict the supply of women. With the exception of our eariler work (Paxton and Kunovich 2003) and Oakes and Almquist (1993), general measures of the share of women in the paid labor force do not predict women's representation. When more specific measures of relevant occupations such as the percentage of women in professional or managerial professions are available, the findings are significant in some studies (Kenworthy and Malami 1999) but insignificant in others (Paxton 1997). 
use of multimember districts, which means more than one candidate can be elected from a particular district. In contrast, plurality-majority systems like the United States ask citizens to vote for single candidates, typically in single-member districts. ${ }^{5}$

An electoral system that uses a proportional representation closed-list system and multimember districts offers several advantages to female candidates (Matland 2002; Norris 1993). Since parties operating under closed-list systems publish lists of candidates, they may feel pressure to balance their party's ticket across genders, leading to greater numbers of women. As a respondent from the Pacific in the IPU study states, "There has been recognition over the last 10 years (1988-98) that it is essential for the credibility of any political party to be seen to be preselecting and electing women to parliament" (IPU 2000, p. 57). In multimember districts, balancing is used to attract voters but also to achieve equity across different factions of the party and resolve internal party disputes through compromise (Matland 2002; Gallagher and Marsh 1988). ${ }^{6}$ In contrast, single-member districts result in zero-sum contests in that parties must make a choice between male and female candidates rather than being able to place both on the ticket. ${ }^{7}$

The extent to which institutions are democratic can also affect the representation of women as candidates and the translation of those candidates into legislators. Fair elections and open competition may be more conducive to women entering politics since fewer artificial and arbitrary constraints would act as barriers. Women can research, understand, and possibly manipulate the rules of the game if they are clearly stated and consistently followed (Matland 2002), suggesting that democracy can help women. Alternatively, in nondemocratic systems women do not have to go through the electoral process and can be placed into power (Abukhalil

\footnotetext{
${ }^{5}$ There are a variety of variations on these two basic types of electoral systems, as well as hybrid systems. We recommend the International Institute on Democracy and Electoral Assistance's Web site (http://www.idea.int/esd/systems.cfm) for a brief overview of electoral systems.

${ }^{6}$ Unfortunately, some of this balancing is not truly meaningful, with women placed in hopelessly low electoral list positions (Gallagher and Marsh 1988, p. 254).

${ }^{7}$ Previous statistical research has clearly demonstrated that proportional representation systems have higher percentages of elected females. Case studies of nations with hybrid systems provide additional compelling evidence. Within a country with both systems, women are elected at much higher rates under the proportional representation system than under the alternative single-position system (Henig and Henig 2001; Norris 1993, p. 313; Rule 1987). For example, after Germany's 1990 election, women won $28 \%$ of the party-list seats and only $12 \%$ of the plurality-majority constituency seats. Similarly, in Australia's 1990 election, women won $25 \%$ of party-list seats but only $7 \%$ of the plurality-majority districts.
} 


\section{American Journal of Sociology}

1997; Howell 2002). Previous research (e.g., Paxton 1997) indicates that this second explanation may in fact be the more likely scenario. ${ }^{8}$

Quotas and legislative appointments are two political mechanisms used in both democratic and nondemocratic nations that may increase women's representation. There are generally two types of quotas-those put forward by the state to apply to all parties, and those established within a particular party. Quotas can either be voluntary or they can be required. When quotas are mandated by the state, they can result in dramatic increases in the proportion of women elected depending on context (e.g., Jones 1998; Schmidt and Saunders 2004; Dahlerup and Freidenvall 2005; Krook 2003, 2004a). Quotas are highly regarded by theorists and female parliamentarians alike as a means of increasing women's representation in politics (IPU 2000; Commonwealth Secretariat 1999, p. 134). Previous research has also demonstrated that when parties adopt required quotas there is an increase in elected female representatives over time, at least among advanced industrial nations (Caul 2001). Even when only a subset of parties adopt quotas, diffusion effects are seen that result in other parties' increasing their percentage of female candidates and representatives (Matland and Studlar 1996; Caul 2001; Lovenduski 1993; McDonagh 2002). ${ }^{9}$

Legislative appointments are another strategy used by the state to increase women's or other groups' overall levels of representation, especially in countries with historic gender, ethnic, or religious inequalities. Legislative appointments reserve a specific number of seats in the legislature and then select individuals to fill those positions after the election. For

${ }^{8}$ Rather than excluding nondemocratic and less democratic countries from an analysis, we feel it is important to model explicitly how democratic processes can influence women's entry into politics. There is evidence that in both emerging democracies and communist nations women aspire to hold positions in the national legislatures (Tripp 2001; Howell 2002). While the political parties within these new democracies may be weak and/or government controlled, women's presence in party leadership should positively impact women's selection as candidates and ultimate election to the national legislature. Finally, nondemocratic governments may have extraelectoral means at their disposal to increase or decrease the ultimate number of female legislators. Studying women's political outcomes in less democratic nations is further necessary because even in an inefficient and relatively weak legislature, women's presence provides an opportunity for women's voices to be heard and can be interpreted by the citizens of the nation as symbolic support for women. Similarly, having no women in the legislature sends a clear message as to the status of women.

${ }^{9}$ Quotas are increasingly being used to increase women's participation in politics. In the late 1990s, 11 nations in Latin America passed national legislation requiring a minimum of $20 \%-40 \%$ female candidates. In France a constitutional amendment in 1999 established that $50 \%$ of candidates must be women (Dahlerup 2002). At the time of our study, however, only a small number of nations had passed federal laws mandating national legislative quotas or systematically adopted political party quotas (Krook 2004b). 
example, in Egypt, the president has the right to appoint 10 seats to the parliament, and these are typically filled by a varying number of women and Christians (Al-Ahram 2000). Appointments are different from quotas because they are "extraelectoral" in that they occur outside the electoral system. Appointments can be considered nondemocratic, in the sense that women who gain legislative position through appointment have not been elected.

Finally, the ratio of effective parties to all operating parties may influence how many women participate in politics. The higher the ratio, the more likely all parties will be elected to a meaningful number of seats. Parties that typically win a meaningful share of seats may be unwilling to go against the status quo and do things differently than in the past. So, a high ratio of effective parties indicates a system with mostly comfortable, possibly complacent, parties. In such a situation, the promotion of women as candidates and their support in elections may not be a high priority. In contrast, if the ratio of effective parties to all operating parties is low, it indicates an increased presence of marginal parties, who may be more likely to take risks on fielding and supporting women as candidates.

Ideology constitutes the third country-level explanation for levels of female participation in parliament. Ideas about women's role and position in society can enhance or constrain women's ability to seek political power (Paxton and Kunovich 2003; Paxton 1997; Arceneaux 2001; McCammon et al. 2001). Ideological arguments state that, even in the presence of favorable political systems or an adequate supply of qualified female candidates, cultural norms can limit women's opportunities to participate in politics (Rule and Zimmerman 1994; Norris and Inglehart 2001).

Ideology is not diffuse or abstract. Ideologies and arguments against women having the right to participate in politics have created very substantial barriers to women's participation for many years. For centuries, Western political theorists such as Aristotle, Rousseau, Hobbes, and Locke justified the exclusion of women from politics, citing their assumed nonrational nature. "If women were to control the government, the state would be in danger, for they do not act according to the dictates of universality, but are influenced by accidental inclinations and opinions" (Hegel 1977, p. 167). ${ }^{10}$

\footnotetext{
${ }^{10}$ The same themes can be found in non-Western philosophy. There, too, women were portrayed as inferior in reasoning and intellect. For example, Walda Heywat, an Ethiopian teacher writing in the 17 th century, cautions, "O man, remember that a woman is weak by nature and less intelligent than man" (Bonevac and Phillips 1992). On another continent and in a different century, Avicenna, an Islamic metaphysician writing around the year 1000, states, "For in reality [woman] is not very rational and is quick to follow passion and anger" (Avicenna 1963). Nizamu'l-Mulk Tusi, writing
} 
American Journal of Sociology

Such attitudes about women in politics persisted even after women gained the right to participate in politics. After having gained suffrage, women found that their ability to make rational decisions was still questioned theoretically and empirically. For example, despite breaking ground in explaining women's electoral participation, Duverger (1955, p. 129) explains sex differences in voting by a psychological female dependency on men: "While women have, legally, ceased to be minors, they still have the mentality of minors in many fields and, particularity in politics, they usually accept paternalism on the part of men. The man-husband, fiancé, lover, or myth-is the mediator between them and the political world."

In the IPU study, female politicians cite a negative ideology more often than any other reason as their explanation for low female participation in politics. As a respondent from Central America states, "The patriarchal ideology prevailing in our society is the biggest stumbling block we have to face" (IPU 2000, p. 61). Another respondent, from Central Europe, contrasts an ideological explanation with structural and political factors:

In spite of a long tradition of active participation in the workforce by a vast majority of women, both women and men see motherhood and marriage as the most important goals in a woman's life. A common standpoint is that "politics is a man's business," and that women are too emotional to deal with affairs of the state. The reasons for this are not to be found in education, with women in [my country] being as educated as their male counterparts. It is simply because of the stereotyped and traditional structure of society. (IPU 2000, p. 20)

It is likely that ideologies about women affect their representation throughout the political process, from individual women's decisions to enter politics, to parties' candidate selection, to the decisions on election day made by the electorate. Indeed, even after women have gained office, cultural norms can limit their effectiveness when dealing with their male counterparts. For example, harassment of women was commonplace in Uganda's parliament (Tamale 1999), and in Bangladesh Islamic fundamentalists turn their backs during speeches by female political leaders (Commonwealth Secretariat 1999, p. 35).

While recent work (Paxton and Kunovich 2003; Norris and Inglehart 2001) finds that a precise measure of gender ideology has a large impact on women in national legislatures, most earlier research relied on proxies for ideology, such as region or religion, as cross-national information on

around the same time, warns his king not to allow women's influence because women are by nature inferior to men in the field of politics and administration (Nizamu'lMulk Tusi 1977). See Giele and Smock (1977, chaps. 2-3) for further discussion of negative historical ideologies in non-Western nations. 
gender ideology is sparse (Kenworthy and Malami 1999; Paxton 1997; Reynolds 1999). A commonly used proxy for ideology is region, with the prevailing ideology of all non-Western regions viewed as negatively affecting the percentage of female candidates and the willingness of the electorate to accept female candidates. While Western industrialized nations certainly have their own biases against women, ${ }^{11}$ women do hold differential status across the regions of the world. Such differences are readily apparent if we consider the measures of ideology available in the World Values Survey (Inglehart et al. 2000). Regressing a range of ideological questions (e.g., "On the whole, men make better political leaders than women do," "A university education is more important for a boy than for a girl") on five regions predicts approximately $70 \%$ of the variance. $^{12}$ The Scandinavian countries demonstrate significantly more positive gender equality views, Asia and Western industrialized countries are at similar levels, and Eastern Europe, Latin America, and other regions demonstrate significantly more negative gender ideology views. Indeed, in predicting women in parliaments, we (Paxton and Kunovich 2003) moved from a model with five regional variables to a model that included the regions plus a direct ideological question, and found that the impact of all regions except Scandinavia could no longer be distinguished from Western industrialized countries and that the coefficient for Scandinavia was halved. ${ }^{13}$

Numbers of religious adherents provide other measures of ideology because religions of the world are differentially conservative or patriarchal

\footnotetext{
${ }^{11}$ Consider an Australian female politician's views: "Social values that it is a women's role to be wives and mothers are still strong in Australia. This creates psychological and emotional barriers to women participating in formal politics" (IPU 2000, p. 25).

${ }^{12}$ Auxiliary analysis is available upon request.

${ }^{13}$ Case studies indicate that attitudes about women differ by region. Scandinavia in particular has been shown uniquely committed to women in politics (see Kelber 1994; Karvonen and Selle 1995). In Scandinavia, there is an ideology that Hernes (1987) describes as a "passion for equality," with extensive commitment to abolishing poverty and achieving social justice through political reform. Scandinavian countries have been practicing this passion for equality in their politics for three-quarters of a century - the first reforms concerning women took place before 1920. Heckscher (1984, p. 172) notes, "It is no exaggeration to say that the fundamental principle of equality between men and women is more widely accepted in Scandinavia than in most other countries of the world; this is seen in legislation, in the apparent attitudes of the public, and in actual practice." Contrast the Scandinavian region to the rigid separation of men's and women's spheres in Middle Eastern countries: "The men's world has two major manifestations: the sphere of earning a living and the public sphere of communications including public affairs. Access of women to the former is limited and formally none in the latter-old grandmothers being an exception" (von Nieuwenhuijze 1965, p. 71). The separation of spheres is an unequal one; in Iran, e.g., women need permission from a husband to work, travel, or divorce.
} 


\section{American Journal of Sociology}

in their views about the place of women, both in the church hierarchy and in society. Generally, religious beliefs can be used by those in power to preserve patriarchal dominance (Botman 1999). And religious legacies leave a distinct and lasting impression on contemporary values and behaviors (Norris and Inglehart 2003).

Generally, conservative religious ideologies promote a less public role for women. Protestant religions vary, but are generally less patriarchal than Catholicism or Islam. Therefore, we expect the strength of adherence to conservative religious ideologies to affect women's performance at the polls negatively. Countries with many Islamic adherents would be expected to have the fewest number of women in their national legislatures, since Islamic law is typically interpreted in a manner that constrains the activities of women (Ahmed 1992; Glaser and Possony 1979) and results in women's lack of control over their own lives (Caldwell 1986, pp. 17576). As explained by the 2003 Nobel Laureate, Shirin Ebadi, "Many people use Islam to justify the unequal position of women. They are wrong" (Associated Press 2004). ${ }^{14}$

The Role of Female Elites in Political Parties

A central argument of our article is that the effects of these national-level factors in producing outcomes for women are at least partially mediated through women's inclusion in political parties. As noted above, parties play an important gatekeeping role in political systems (Caul 1999; Sanbonmatsu 2002; Kunovich 2003). Political parties make decisions about what candidates to field and how much support to give them (e.g., through placement on party lists). As an IPU respondent from Central America states, "the 'key' is undoubtedly the political parties" (IPU 2000, p. 96). In this article, we consider how the presence of women in the party elites of political parties influences their selection and support of women as candidates. ${ }^{15}$

The presence of many women in the party elite of a country should

${ }^{14}$ Islam is not a monolithic trait: there is variation across countries and across individuals (Abukhalil 1997). More generally, there is certainly variation in the expected roles and place of women within regions (and even within countries, see Jejeebhoy and Sathar 2001). Still, without more precise measures of gender ideology, the religious and regional proxies provide some information about important ideological differences across nations.

${ }^{15}$ While other features of parties, such as their organizational structures, rules, and ideologies, have been found to be important in women's representation in Western and Eastern Europe (Caul 1999; Kunovich 2003), we limit our focus to only those aspects of parties that can be measured cross-nationally at the present time. Unfortunately, we know of no systematic cross-national measures of party organizational structures, rules, and ideologies. 
increase the overall number of women fielded as candidates for at least three reasons. First, high percentages of women in party elites may indicate a greater supply of qualified (or perceived to be qualified) women for the parties of a country (Sanbonmatsu 2002). Second, membership in such positions are seen as a "necessary apprenticeship before a party member is considered worthy of selection as a candidate" (Henig and Henig 2001, p. 48). Finally, female party elites may themselves advocate a greater number of female candidates (Caul 1999). As a female legislator from Western Europe stated: "It was the women in the party who encouraged me to get more deeply involved and to register on a list for the elections" (IPU 2000, p. 75). Female party elites should also positively affect the ratio of representatives to candidates since they may be able to better support female candidates in their bids for election, influencing list placement or party contributions to candidate war chests. Consider this West African respondent: "Women asked me to stand in the legislative elections and they supported my candidacy in the one-party state system" (IPU 2000, p. 82).

Of course, women in elite positions need not act in the interests of other women. As stated succinctly by Lovenduski (1993, p. 6), "A great dilemma for the second wave of feminism has been whether women will change institutions before institutions change women." Female leaders may feel the need to follow party rules, wish to avoid seeming to play favorites, or simply have concerns that outweigh their gender identity. As Lovenduski summarizes in the introduction to her edited volume on women in parties: across the 11 cases studied, party divisions tended to outweigh gender divisions (Lovenduski and Norris 1993).

Still, as those who study the candidate selection process argue, the attitudes and values of the candidate selectors matter for who is selected. Presumably, some percentage of female party elites would actively look to promote women as candidates. Indeed, $78 \%$ of women responding to the IPU survey believed that the presence of women had brought about a change in their party's priorities. And women may be better able to see what must be done to recruit female candidates. As documented by the Commonwealth Secretariat (1999, p. 20), in Australia, a current female party leader made it possible for a former female party leader to return to politics (and ultimately be elected) by promising to make all the necessary flexible arrangements so that the she could juggle the demands of a new baby.

For these reasons, we argue that higher average levels of women in elite party positions (across all parties) should positively influence the countrywide representation of women as candidates. More specifically, we can distinguish women's inclusion as highly visible party elites such 
American Journal of Sociology

as party chairperson, vice chairperson, or spokesperson, from the presence of women in the party bureau, which is the governing body of the party.

Mediation

Figure 1 hypothesizes that the presence of women in party elites mediates the country-level variables in producing political outcomes for women. How would this process work? Some of the country-level effects may be completely mediated through political parties, while others are likely to continue to have direct effects on the percent of female candidates nationally. Considering the categories of country-level variables, it is most likely that the structural factors will be mediated through the parties, as they suggest the "supply" of potential candidates that can be picked up by these parties. In contrast, the national ideology of a country is likely to continue to have a direct effect on outcomes down the line of sequential outcomes. This is because, despite women's general inclusion in the workforce or education, parties know that women's leadership must be ideologically accepted by the population at large. It is an open question whether country-level political factors will continue to have a direct effect after the mediating party variables are included. Ultimately, we expect that while some country-level variables may continue to have direct effects on women in national legislatures, the direct path may not exist for others, with all influence working through party processes.

\section{Interaction}

Rather than being influenced by their electoral system, political parties may operate differently across proportional representation and pluralitymajority systems. As Gallagher and Marsh (1988, p. 260) explain, "The electoral system strongly affects the mechanics of the selection process in every country." Each electoral system offers different opportunities and constraints for party elites, indicating a possible interaction effect rather than simple mediation. ${ }^{16}$ For example, Czudnowski (1975, p. 221) argues that when seats are assigned proportionally, using party lists, the central party has much more influence on candidate selection.

As for a party's selection of female candidates, party gatekeepers' perception of women as desirable candidates depends on their country's electoral system (Matland 2002). "Qualities which candidate selectors might feel, accurately or otherwise, could be electoral liabilities in a party's sole candidate, like being a woman or a member of an ethnic minority,

${ }^{16}$ We thank the AJS reviewers for asking the questions that led us to consider this interaction effect. 
are needed for purposes of balance when several are being picked" (Gallagher and Marsh 1988, p. 260). Thus, female leaders may find it easier to get women on the ballot in proportional representation systems because they are not fighting a zero-sum process. However, considering that ticket balancing is often combined with "hopeless" list placement (placement on a list below the number of seats a party can reasonably expect to win), female leaders in proportional representation systems may be less able to produce gains for women as elected officials. ${ }^{17}$ That is, while female elites may be able to articulate the need for female candidates under a proportional system, they may be less successful in getting them placed in winnable positions on lists.

\section{DATA AND MEASURES}

All data pertaining to women's presence in party elites, the percentage of female candidates, and the percentage of female representatives were collected by the IPU and made available in their 1997 publication $D e$ mocracy Still in the Making: A World Comparative Study. The IPU surveyed national legislative bodies to obtain data for elections occurring between August 1991 and December 1996 for all countries. In a substantial number of countries the political parties participating in these elections provided data about women's participation in the party, their inclusion as electoral candidates, and their electoral outcomes. We analyze data for all countries where both the percentage of female candidates and the percentage of women elected are available.

Even though not all countries provided these data, there is remarkable regional variation. As discussed above, table 1 contains information on the percentage of female candidates, percentage of female legislators, and the ratio of the two for the 73 countries in our analysis. In the following sections we describe all variables used in our analysis (for a summary of this information, see app. table A1).

\section{Women's Inclusion in Political Party Elites}

Within each country, the IPU surveyed political parties participating in the election for an assortment of data. We used the party's responses to

\footnotetext{
${ }^{17}$ Since individual candidates are typically less important in proportional representation systems, female elites can also not differentially support female candidates to help them win. The exception is open-list proportional representation systems, where voters can prioritize among the list of candidates. However, when organized listswitching drives to improve women's position on party lists were tried in the past (e.g., Norway's local elections in the 1970s), they ultimately backfired (Matland 2002).
} 
American Journal of Sociology

construct aggregate measures of party characteristics at the national level. We measure our first outcome, women's inclusion in party elites, with two variables. The percentage of women in leadership positions is based on the percentage of women who occupied five possible positions of power across parties: party chairperson, party vice-chairperson, secretary general, party spokesperson, and head of the parliamentary group. To calculate the percentage, we pooled the parties and calculated the percentage of women who held those positions across all of them. Women held $10 \%$ of the positions of power on average across the countries of our sample.

Our second measure of women's inclusion in party elites is the percentage of female party bureau members. Generally the party bureau is regarded as the governing body of the party and is responsible for establishing and enforcing party rules. In a similar manner to women's presence in leadership positions, we pooled all parties and determined the percentage of female party bureau members across all parties. For example, if a country had three parties where the percentages of female party bureau members were $30 \%, 15 \%$, and $5 \%$, this country would then be assigned an average value of $16.7 \%$. Women accounted for $17 \%$ of members of the party bureau on average.

\section{Female Candidates}

Our second outcome is women's selection as candidates. We calculated the percentage of female candidates for the country by dividing the total number of female candidates by the total number of candidates running for election. On average women accounted for $15 \%$ of female candidates with a low of less than $1 \%$ in Jordan and Yemen and a high of $50 \%$ in Iceland.

\section{Women in National Legislatures}

Our third outcome is women's election to the lower house of the national legislature. We calculated the percentage of women in the national legislature by dividing the total number of women elected by the total number of positions in the legislature. In cross-national studies, representation in the lower house rather than the upper house is used because in countries with two legislative chambers, lower houses generally have more legislative power than upper houses. On average women accounted for $12 \%$ of representatives with a low of no women in Kiribati to a high of $40 \%$ female representatives in Sweden. 
Pathways to Power

Ratio of Female Elected Officials to Female Candidates

An alternative outcome of interest is the yield of female representatives from the female candidates. We create a ratio measured as the percentage of female representatives elected to the lower house of the national legislature divided by the percentage of female candidates. Values of one indicate a one-to-one relationship between percentage of candidates and percentage of female representatives. In our sample the yield of female representatives ranges from values of considerably less than one (e.g., 0.3 in Morocco) to values greater than one (e.g., 1.22 in the Netherlands). Thus, while the "return" on female candidates is very low in Morocco, $3 \%$ female elected officials for every $10 \%$ female candidates, the return is greater than expected in the Netherlands. ${ }^{18}$

\section{National-Level Factors}

Our exogenous national-level variables are measured per previous research. Our models include three social structural variables. As in previous research, we include the percentage of the economically active population who are women (women economically active) and the percentage of tertiary students who are women in 1990 (women tertiary education; United Nations 2000). As discussed above, these measures control for the size of the eligible pool of women for political office. ${ }^{19}$ We also include the log of energy use per capita in 1995 (World Bank 1999) as a measure of industrialization. Structural arguments predict that a certain level of development frees up time for women to pursue political careers. Although not included in every model of women in politics, industrialization has been found to be significant in some previous research (Paxton 1997). The inclusion of industrialization also controls for developmental differences across the regional variables.

A key political variable is a country's electoral system. The variable PRPL electoral system identifies those countries that use a proportional representation party-list (PRPL) system to elect any seats in their national

\footnotetext{
${ }^{18}$ Although the ratio can generally be viewed as a return on candidates, there are a few other factors that can influence it. For example, female legislative appointments may artificially raise a country's ratio because women are being placed into legislative positions without running as candidates.

${ }^{19}$ Ideally we would like to measure the percentage of women with a tertiary degree in 1990. However, these data are not widely available cross-nationally. Therefore, research in the area routinely uses the percentage of women in tertiary education to measure women's access.
} 
American Journal of Sociology

legislatures..$^{20}$ Another political variable included in our analysis is a country's level of democracy. Liberal democracy is measured using Bollen's (1998) political democracy index; a value of 100 is the maximum, indicating a well-functioning system and regular use of democratic procedures. $^{21}$

To control for nondemocratic access to the legislature for some groups through the use of reserved seats, we include a dichotomous measure called appoint (United Nations 1995) to indicate whether a country appoints members to the national legislature on the basis of gender, ethnicity, or religious affiliation. We also control for countries where parties require that a certain proportion of candidates be women or where national laws mandate the increased representation of women through the use of quotas. Our final political variable is the ratio of effective parties and is based on data from two sources. The number of effective parties comes from Derbyshire and Derbyshire (1996) and is a count of the number of parties with $10 \%$ or more of assembly seats. The total number of parties competing comes from the data collected by the IPU (1997). We divide the number of effective parties by the total number of competing parties to control for the influence of marginal parties. A value of 100 indicates that all parties typically receive at least $10 \%$ of the available seats.

As noted above, ideology has traditionally been measured with proxies such as region and religion. In our analyses, we include six regional dichotomous variables: Africa, Asia, Eastern Europe, Middle East, Latin America, and Scandinavian countries. Western industrialized countries are the omitted category. ${ }^{22}$ To measure religion, we include the percentage of Catholics, Muslims, and Orthodox religious adherents (World Almanac 1996). Not all nations adhere to religions; instead, individuals within those nations adhere to religions. So, using a percentage measure rather than a dichotomous variable acknowledges variation within countries considered predominantly "Muslim," "Catholic," or "Orthodox." Also, it is reasonable to assume that larger groups of conservative adherents are better able to use their religious beliefs to influence women's selection and rep-

\footnotetext{
${ }^{20}$ While electoral systems are relatively fixed characteristics of the political environment some countries experienced a change between their electoral system in 2003 and the one in place when these data were collected. Therefore, we used both the Chronicle of Parliamentary Elections and Derbyshire and Derbyshire (1996) to identify the electoral system. The reference category includes all other types of electoral systems, such as first past the post, single transferable vote, and mixed systems that do not include a PRPL system. Together, these reference category electoral systems are generally plurality-majority systems in that candidates must individually obtain a certain percentage of the vote (a plurality or majority) to obtain political office.

${ }^{21}$ To get 1995 data, we used an updated version of Bollen's (1998) data set.

${ }^{22}$ For the exact classification, see table 1.
} 
resentation as political figures. Although regional and religious proxies are inferior to more precise measures of ideology, our earlier work (Paxton and Kunovich 2003) demonstrates that these are indeed good proxies for ideology when a more precise measure is unavailable. ${ }^{23}$

Research Model and Methodology

Given the nature of the electoral process, the constituent variables have a causal ordering that we assume is unidirectional (see fig. 1). In most political parties, party elites and party bureau members are put in place prior to the candidate selection process and subsequently oversee the process. Since the selection committee is established prior to candidate selection we are able to use cross-sectional data that documents the percentage of women in party leadership positions at the time the candidates were selected and ultimately elected. Thus, we estimate a recursive model in which we hypothesize that each exogenous variable will affect all endogenous variables and that endogenous variables occurring earlier in the electoral process will affect endogenous variables occurring later in the electoral process. We can therefore determine both the direct and indirect effects of our national-level variables. ${ }^{24}$

Missing data were accounted for using multiple imputation procedures (Allison 2002) available in the SAS statistical package. ${ }^{25}$ This procedure allowed us to retain the full 73 cases and is the most appropriate method

${ }^{23}$ Unfortunately, the available sample of countries constrains our ability to use the national gender ideology measure we developed earlier (Paxton and Kunovich 2003).

${ }^{24}$ It could be argued that the full model is nonrecursive in one important respecthigh levels of legislative participation by women could influence gender ideology through increases in citizens' comfort with women in politics. In our earlier work (Paxton and Kunovich 2003, pp. 101-2), we tested this hypothesis directly with a Hausman endogeneity test and found that the percentage of women in the legislature does not have a reciprocal effect on gender ideology. Of course this endogeneity test does not rule out a reciprocal effect over a longer time period. Indeed, we would expect any effect of legislative participation to have a long-term effect on gender ideology, much longer than the period considered here.

${ }^{25}$ Using available data, the imputation procedure generates estimates, including a random component, for each of the missing values. Treating imputed cases like real data would produce artificially low SEs, so the random imputation is carried out several times, producing multiple full data sets. The variability across these multiple imputations is then used to adjust the SEs upward. In addition, variables not used in the model were included in the imputation model to improve the accuracy of the imputed values. These included date of women's suffrage, a scale of abortion rights, and the percentage of women in the country's national legislature in 1980. Variables were transformed where necessary to produce appropriate imputed values. For imputing female party elites, the arcsine transformation is preferable to the logit or probit, because the arcsine is defined for proportions that take values of zero (von Hippel 2003). 


\section{American Journal of Sociology}

when sample sizes are small. As with any small cross-national sample, demonstrating robustness is crucial—we therefore considered whether any outliers were influential to the results.

\section{RESULTS AND DISCUSSION}

In table 2 we provide unstandardized path coefficients and standard errors for the model depicted in figure 1 .

\section{Country-Level Effects}

Country-level ideology, politics, and structure all affect political outcomes for women. Across the ideological factors we generally see effects of the regional variables on women's inclusion in parties and as candidates. Asia and Latin America are consistently lower than the West, while Scandinavia is generally higher. For example, net of other factors, countries in Asia had $11 \%$ fewer women in party bureaus than did the Western industrialized countries. Countries in Latin America had 16\% fewer women in party leadership positions than found in Western industrialized countries. In comparison to the Western industrialized nations, Scandinavian countries had $20 \%$ more women in party bureaus and a positive but not significant difference with respect to women in leadership positions.

The regional ideological proxies have an impact on the percentage of female candidates fielded by the parties of a country, even after their indirect effects through women's inclusion in party elites are controlled. That is, the ideological variables continue to have a direct effect as well as indirect effects. For example, we see that the Scandinavian countries have almost $12 \%$ more candidates while countries in Asia and Latin America have between $8 \%$ and $12 \%$ fewer candidates than Western industrialized nations.

Among the religious measures of ideology, the effects of conservative religious ideologies on the mediating party variables are also generally negative, although substantially weaker than the regional proxies. Only percentage Catholic has a significant effect on women in party elites. The effect is fairly small; countries with $20 \%$ more Catholics have $2.2 \%$ fewer women in party bureaus. The percentage Muslim and percentage Orthodox in a country do negatively affect the percentage of female candidates, however. Having $20 \%$ more Muslim adherents in a country results in almost $4 \%$ fewer female candidates. ${ }^{26}$

${ }^{26}$ Multicollinearity is an issue here. It is difficult to separate the effect of Muslim from that of the Middle East in this sample. Reflecting this uncertainty, diagnostics suggest that the SEs for those two variables are substantially inflated. Removing Muslim 
It is interesting that although the ideological proxies have an impact on the percentage of female candidates, they do not influence the percentage of female elected officials or the ratio of elected officials to candidates (the "return" on candidates). ${ }^{27}$ This suggests that while parties are reducing or increasing their numbers of female candidates in response to their perceived acceptability as candidates, women are actually not any more unacceptable as candidates in any region. Research on Western industrialized countries has often shown that the public is willing to elect women when they are nominated as candidates (Welch and Studlar 1986). Our results indicate that this is true across a variety of regions.

In contrast to the ideological effects, the structural factors have fewer significant effects on political outcomes for women. We do see that countries with $10 \%$ more women attending tertiary education have $2 \%$ more women in leadership positions. What is more surprising is that the effect of women's economic activity on women's inclusion as party elites is the opposite of what is typically hypothesized. With each single-unit increase in women's economic activity (measured as a percentage) there is a .31 decrease in the percentage of female party bureau members and a .45 decrease in the percentage of women in leadership positions. ${ }^{28}$ In other words, countries with $10 \%$ more women in the labor force have $3 \%$ fewer women in party bureaus and $5 \%$ fewer women in positions of leadership.

The negative effect of women's labor force participation is unexpected, but perhaps not unreasonable. Without information on the types of jobs in which women work, it is unclear whether women are gaining politically relevant human capital from their job or are simply working too many hours to find the time to participate politically. This argument is supported by two pieces of evidence. First, an examination of the relationship between women's economic activity and women's presence in the party bureau and leadership position shows that countries in Southeast Asia and Eastern Europe are concentrated at high levels of economic activity and low levels of inclusion. The concentration of countries in Southeast Asia is best explained by a distinction between jobs that provide skills and resources that can be translated into political capital versus jobs that

countries from the analysis (countries with greater than $80 \%$ Muslim adherents) is not an option in this sample because it would leave only one country that could be classified as Middle East-Cyprus. Still, if the Muslim countries are removed from the sample (and Cyprus is reclassified as African), it makes no difference to the rest of the results, except that the effect of women economically active is reduced and no longer significant.

${ }^{27}$ In the legislator equation, Scandinavian countries continue to have a slight advantage $(4 \%)$ over other Western industrialized nations in the percentage of women that are elected. Only the percentage of Orthodox adherents in a nation continues to negatively affect the percentage of women elected, controlling for the other factors.

${ }^{28}$ This effect is significant and stronger if one outlying case, Samoa, is removed from the analysis. 


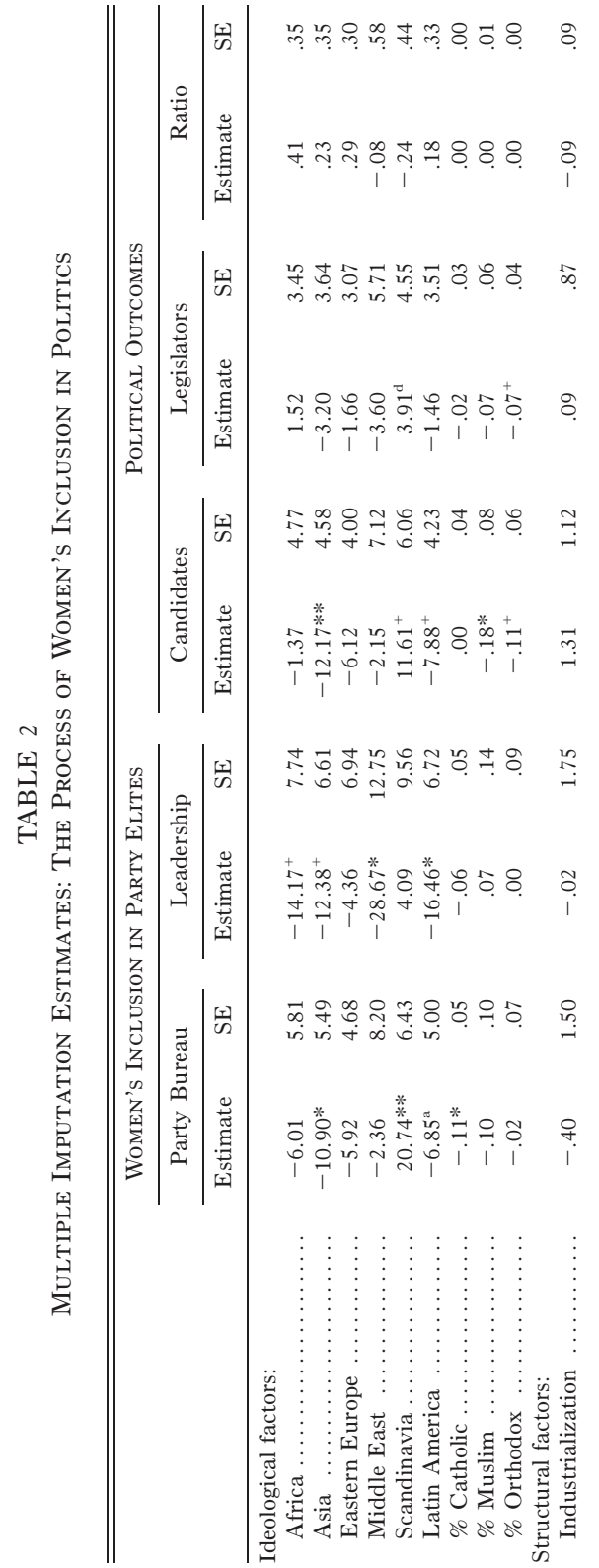




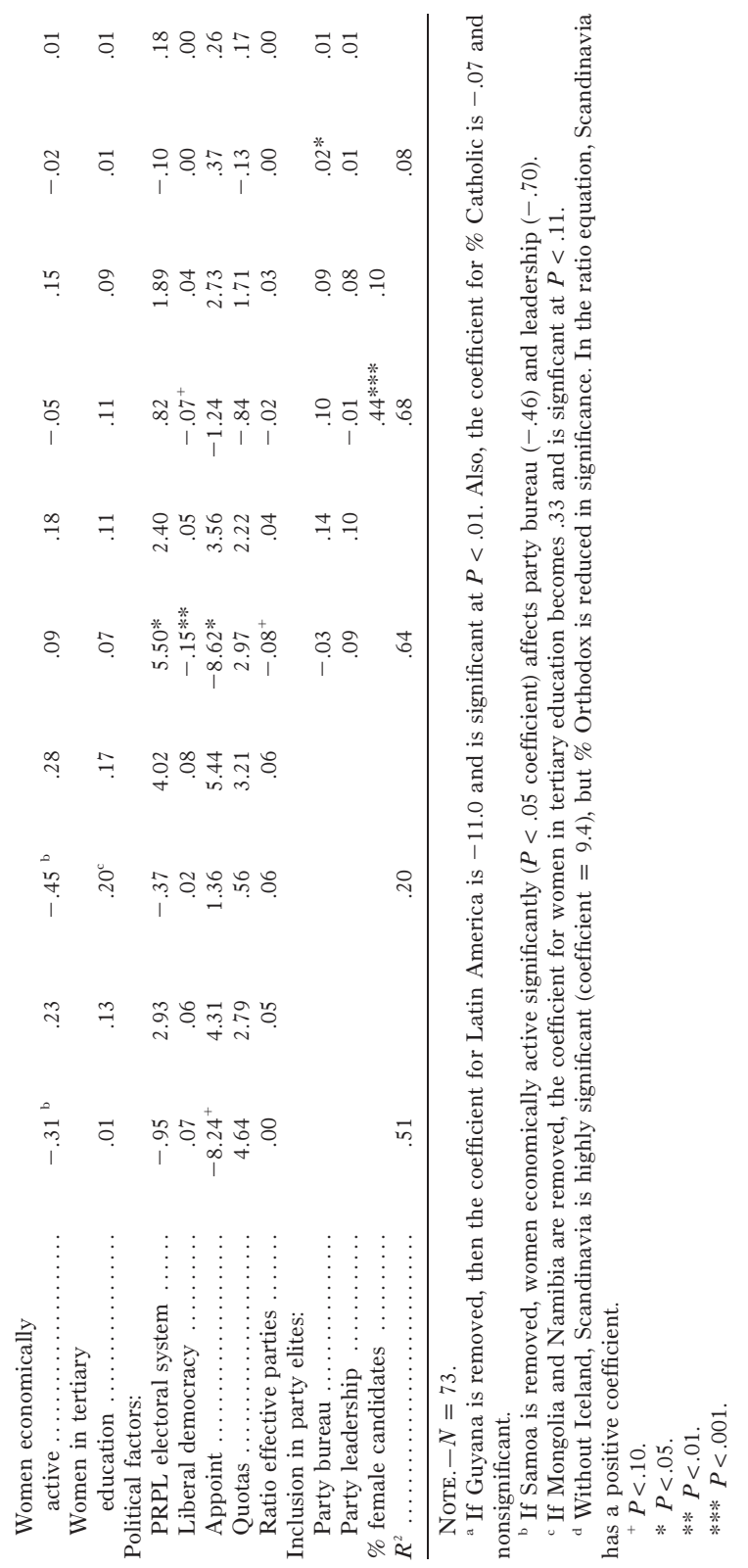


exploit women for the low cost of their labor. In fact, Matland (1998) found that across less developed countries, women's economic activity negatively affected their rate of election (although his coefficient was nonsignificant). Similarly, others have argued that the withdrawal of women from politics in Eastern Europe was in part because of the triple burden (work, politics, and home) they experienced under communism (Nechemias 1994; Wolchik 1993). Eight women in the IPU survey mentioned how their careers helped prepare them for a career in politics. All eight were professionals; four were lawyers, two were journalists, one was an engineer, and one was an economist (IPU 2000, p. 84).

The second piece of supporting evidence is based on an auxiliary analysis that includes the percentage of women in professional positions. These results show that, although nonsignificant, the coefficient is positive, so that as the percentage of women in professional positions increases, there is an increase in the percentage of women in the party bureau and leadership positions. Thus, a more precise measure of employment that increases human and financial capital yields coefficients in the expected direction. ${ }^{29}$

It is also important to note that the effects of the structural variables are generally mediated by the party characteristics. Structural factors do not have any effect on female candidates, elected representatives, or the ratio of female elected officials to candidates. The fact that none of the structural factors are significant suggests that differences in women's participation in other public spheres, such as the labor force and education, do not directly explain the underrepresentation of women. Instead, these structural factors work only indirectly, through their impact on political parties.

Turning to the political, we find that PRPL systems do not significantly affect women's inclusion as party elites or their representation in the legislature once female candidates are controlled. Instead, the effect of a proportional representation system is exactly where we expect-on candidates. Proportional representation list systems have 5\% more female candidates than do other systems. This finding supports the argument that a PRPL system holds parties accountable to voters and results in the selection of more female candidates for balance. However, a party-list system does not improve women's situation within the political party. This may be because the sex composition of leadership positions and party bureaus receive less public scrutiny.

We find that liberal democracy has a negative effect on the percentage

\footnotetext{
${ }^{29}$ There was a great deal of missing data on women in professional occupations, however, and given the lack of a significant effect we do not include the variable as part of our main analyses. Auxiliary analyses are available upon request.
} 
of female candidates, controlling for other variables. This finding is not unprecedented (Paxton 1997). The negative effect of liberal democracy results from the fact that less democratic countries, such as Cuba, North Korea, and Vietnam, are able to manufacture high legislative percentages of women precisely through a lack of democratic institutions. When women do not have to experience a competitive democratic system, they can be placed into political positions. The well-documented decrease in women's national legislative participation in Eastern Europe after the fall of communism demonstrates the sometimes surprising effect of democracy on women in politics (Saxonberg 2000; Matland and Montgomery 2003). Indeed, in auxiliary analyses where the least democratic countries of our sample were removed (Algeria, Cuba, Iran, Laos, North Korea, Vietnam, and Yemen), there was no significant effect of democracy on either candidates or legislators.

An additional result to highlight here is the negative effect of a national policy of nonelected appointment to the national legislature on women's inclusion in parties and as candidates. Legislative appointments decrease the percentage of women in the party bureau, as well as the percentage of female candidates, without an appreciable impact on the percentage of female legislators. Thus, country-level mechanisms to increase disadvantaged groups such as women at the legislative level appear ultimately to negatively impact women's participation through their indirect effects on the percentage of female candidates fielded by political parties. ${ }^{30}$ It may be that party officials do not feel responsible to promote women or other disadvantaged groups from within their own parties when the state takes on the role of appointing such groups to the national legislature. This finding suggests that the unintended consequence of national formal procedures to increase the representation of traditionally underrepresented groups might actually discourage political parties from actively supporting these groups themselves. ${ }^{31}$

We also find that quotas at the national or party level do not result in increases for women on any outcome, including the percentage of female

\footnotetext{
${ }^{30}$ Without longitudinal data we are unable to definitively show that the percentage of female candidates declines as a direct result of the use of appointments. Data for Egypt are suggestive, however. In 1976, prior to presidential appointments, only six women were elected. Between 1979 and 1990, anywhere from five to seven women were elected, while 7-30 women were appointed. However, the size of the legislature increased from 392 seats in 1979 to 454 seats in 1990 so that women held a smaller proportion of elected seats after the adoption of presidential appointments (IPU 1995, p. 113).

${ }^{31}$ Legislative appointments are viewed as further problematic because occupants are not held accountable, and the seats can be easily withdrawn. When seats are reserved specifically for women, the system may give the impression that women are not fit to contest for the general seats (Commonwealth Secretariat 1999, pp. 28-35).
} 


\section{American Journal of Sociology}

candidates. ${ }^{32}$ We remain cautious in our interpretation of this lack of an effect, however, because not all quotas are created equal. In fact while some countries mandate $10 \%$ of candidates, others mandate $30 \%$. If parties tend to only meet the minimum requirements required by quota laws, then women's chances of being candidates in countries with a low threshold are clearly compromised. In addition, while one party in a country might use quotas, the other four parties operating in a system might not. Finally, if list positions are not explicitly stated (e.g., alternation of men and women), parties can circumvent the spirit and purpose of the quota system by only placing women in list positions or electoral districts they already expect to lose (Freedman 2004). ${ }^{33}$ As an IPU Central European respondent explains, the "country list has to include 25 women. Unfortunately they were in the second part of the list" (IPU 2000, p. 65).

Ideally, therefore, one would measure particular aspects of the quota system and the extent of its use rather than simply relying on a dichotomous indicator. Unfortunately, with so few countries using quotas during this election period we were unable to follow this strategy. As information on the number of countries and parties adopting quotas increases, researchers will be able to tease out the effects of party versus national quotas, differences in quota thresholds across countries, and quotas requiring certain list placements. ${ }^{34}$

We find that as the ratio of effective parties to all parties increases, there is a decrease in the percentage of female candidates. A $10 \%$ increase in the ratio of successful parties results in approximately $1 \%$ fewer female candidates. This indicates that complacent parties may feel little need to increase numbers of women, and that innovation must come from smaller, more marginal parties. Indeed, a respondent in the IPU survey who left a major political party to run a slate of women as independents stated,

\footnotetext{
${ }^{32}$ In order to determine the independent effects of national quotas and party quotas, we measured their effects separately. In this model neither measure had a significant effect on any of the outcomes. We attribute this to the fact that prior to 1996 few countries had adopted these types of quotas. The political situation as of 2005 , however, is quite different.

${ }^{33}$ Voters can circumvent quotas too-Jones and Navia (1999) find that quotas are less effective in open-list proportional representation systems where voters can prioritize candidates.

${ }^{34}$ The International Institute for Democracy and Electoral Assistance (IDEA) has recently released the "Global Database of Quotas for Women," which provides very detailed information on types of quotas across countries. The database cannot be used for the current analysis, however, because the elections we analyze occurred prior to the institution of many of the quotas recorded in the database. As the quota database does not provide dates of implementation for all countries, we were unable to determine whether the quotas reported there applied during the election we studied.
} 
"There were endless frustrations there. Political parties need to be totally overhauled and reformed" (IPU 2000, p. 99).

Finally, it is worth noting that once female candidates are included in the legislators equation, few other variables reach statistical significance. Clearly, the percentage of women that make it to parliament is heavily dependent on the percentage of women who run. It is also worth noting, however, the small return for female candidates, as indicated by the coefficient of .44. A $10 \%$ increase in female candidates yields only a $4 \%$ increase in female legislators, once other variables are controlled. As we shall soon see, however, this yield can be influenced in certain circumstances.

\section{The Impact of Women in Elite Party Positions}

We have argued that women's presence in party elites will influence the percentage of female candidates fielded in a country and how many legislators those candidates yield. Our results demonstrate that these party characteristics have mixed effects on female candidates and legislators and ultimately depend on the type of electoral system being considered. To begin, in table 2 we find that women's inclusion among party elites, measured both as members of the party bureau and by holding leadership positions, does not significantly affect the percentage of female candidates or legislators and has only modest effects on the yield of female elected officials from these candidates (a 10\% increase in the percentage of female party elites leads to a .2 increase in the ratio, less than half an SD change). ${ }^{35}$

However, as indicated by table 3 , the picture is quite different if we consider the interaction between a PRPL electoral system and women in party elites. In brief, the significant interaction effects suggest that female party leaders are able to produce more female candidates in proportional representation systems. But, female party leaders can help female candidates get elected in plurality-majority (nonproportional representation) systems. ${ }^{36}$

Interpreting the interaction effect in column 1 of table 3 is straightforward since PRPL electoral system is coded as a dichotomy. The effect

\footnotetext{
${ }^{35}$ Modeling the percentage of women in parliament without the party variables (party bureau, party leadership, and female candidates) results in a lower $R^{2}(.57)$ and findings similar to those in previous research.

${ }^{36}$ We considered two other interactions of female party elites with country-level political characteristics: democracy and the ratio of effective parties to all operating parties. Neither of the interactions was significant. In addition, we investigated possible nonlinear interactions with democracy (e.g., an interaction between female party elites and the most nondemocratic countries in our sample). There was no indication of a nonlinear interaction between party elites and democracy either.
} 
TABLE 3

Multiple Imputation Estimates, Interaction between Electoral System and Women in Party Elites

\begin{tabular}{|c|c|c|c|c|c|c|}
\hline & \multicolumn{6}{|c|}{ Political Outcomes } \\
\hline & \multicolumn{2}{|c|}{ Candidates } & \multicolumn{2}{|c|}{ Ratio } & \multicolumn{2}{|c|}{ Legislators } \\
\hline & Estimate & SE & Estimate & $\mathrm{SE}$ & Estimate & $\mathrm{SE}$ \\
\hline \multicolumn{7}{|l|}{ Ideological factors: } \\
\hline Africa $\ldots \ldots \ldots \ldots \ldots$ & -2.49 & 4.78 & .42 & .35 & 1.85 & 3.34 \\
\hline Asia $\ldots . . . . . . . . . . .$. & $-14.51^{* *}$ & 4.60 & .31 & .37 & -2.39 & 3.66 \\
\hline Eastern Europe .... & -6.00 & 3.82 & .29 & .29 & -1.29 & 2.88 \\
\hline Middle East ........ & -1.76 & 6.84 & -.24 & .62 & -4.13 & 5.72 \\
\hline Scandinavia ........ & -2.04 & 7.22 & .38 & .55 & 7.16 & 5.35 \\
\hline Latin America ..... & $-10.19^{*}$ & 3.99 & .33 & .35 & -.94 & 3.42 \\
\hline$\%$ Catholic ......... & .00 & .04 & .00 & .00 & -.01 & .03 \\
\hline$\%$ Muslim .......... & $-.23 * *$ & .08 & .00 & .01 & .05 & .06 \\
\hline$\%$ Orthodox ........ & $-.11^{*}$ & .05 & .00 & .00 & $-.07^{+}$ & .04 \\
\hline \multicolumn{7}{|l|}{ Structural factors: } \\
\hline Industrialization $\ldots$ & .86 & 1.08 & -.05 & .09 & .23 & .83 \\
\hline $\begin{array}{l}\text { Women economi- } \\
\text { cally active } \ldots . . .\end{array}$ & .01 & .17 & -.01 & .01 & -.07 & .15 \\
\hline $\begin{array}{l}\text { Women in tertiary } \\
\text { education } \ldots \ldots \ldots\end{array}$ & .07 & .10 & .01 & .01 & .12 & .08 \\
\hline \multicolumn{7}{|l|}{ Political factors: } \\
\hline $\begin{array}{l}\text { PRPL electoral sys- } \\
\text { tem } \ldots \ldots \ldots \ldots \ldots \ldots\end{array}$ & -5.86 & 4.37 & .45 & .36 & -1.40 & 3.25 \\
\hline $\begin{array}{l}\text { Liberal demo- } \\
\quad \text { cracy } \ldots \ldots \ldots \ldots . . .\end{array}$ & $-.15^{* *}$ & .05 & .00 & .00 & $-.07^{+}$ & .04 \\
\hline Appoint $\ldots \ldots \ldots \ldots$ & $-9.55 * *$ & 3.34 & .41 & .26 & -.94 & 2.62 \\
\hline Quotas ............. & 2.56 & 2.13 & -.11 & .18 & -.88 & 1.58 \\
\hline $\begin{array}{l}\text { Ratio effective par- } \\
\text { ties } \ldots \ldots \ldots \ldots \ldots \ldots\end{array}$ & $-.10 *$ & .04 & .00 & .00 & -.01 & .03 \\
\hline \multicolumn{7}{|l|}{$\begin{array}{c}\text { Inclusion in party } \\
\text { elites: }\end{array}$} \\
\hline Party bureau ....... & -.23 & .18 & $.04 * *$ & .01 & .11 & .13 \\
\hline Party leadership ... & .09 & .13 & .00 & .01 & -.04 & .12 \\
\hline \multicolumn{7}{|l|}{ Interactions: } \\
\hline $\begin{array}{l}\text { Party bureau } \times \\
\quad \text { PRPL } \ldots \ldots \ldots \ldots \ldots\end{array}$ & $.53^{*}$ & .23 & $-.04 *$ & .02 & .03 & .18 \\
\hline $\begin{array}{l}\text { Party leadership } \times \\
\text { PRPL .............. }\end{array}$ & .23 & .21 & .01 & .02 & .16 & .17 \\
\hline $\begin{array}{l}\% \text { female } \\
\text { candidates } \ldots . . . .\end{array}$ & & & & & $.49 * * *$ & .11 \\
\hline$R^{2} \ldots \ldots \ldots \ldots$ & .68 & & .13 & & 0.72 & \\
\hline
\end{tabular}


of a $1 \%$ increase in female party bureau members results in a .3 increase in female candidates in PRPL systems $(-.23+.53[1])$ but a .2 decrease in female candidates $(-.23+.53[0])$ in other systems. Looking at a larger increase, we see that a $10 \%$ increase in female party bureau members results in $3 \%$ more female candidates in PRPL systems but $2 \%$ fewer candidates in other systems. ${ }^{37}$

These results are exactly what we would expect, considering what we know about differences between proportional representation and plurality-majority systems. As noted in the discussion above, candidate selectors in PRPL systems feel pressure to balance their party's list for both external reasons (voters) and internal reasons (factional peace). Thus, it should be relatively easy for female party elites in PRPL systems to convince the party to field female candidates. In contrast, plurality-majority candidate selection is a messy, zero-sum process, where the inclusion of a woman necessarily indicates the exclusion of a man (Matland 2002). Our results suggest that under such competitive circumstances, having women in some positions of leadership may actually result in a trade-off for women as candidates.

In contrast, turning to the yield of legislators from female candidates (see the ratio column of table 3), we see something quite different. Increases in female party bureau members do not increase the ratio of legislators from female candidates in PRPL systems $(.04+-.04[1]=0)$. Instead, for this outcome, nonproportional representation systems show a positive effect of women in leadership positions $(.04+-.04[0]=.04)$. A $10 \%$ increase in female party bureau members in a non-PRPL system lead to a .4 increase in the ratio of elected women to candidates. The standard deviation for ratio is .53 , so this is a relatively large effect size.

These results suggest that female leaders in PRPL systems are less able than their counterparts in plurality-majority systems to increase the electability of their female candidates. Again, this is reasonable given differences across the electoral systems. In PRPL systems, candidates appear on lists, and voters typically vote for the party (and its list), rather than for individual candidates. So, female leaders in PRPL systems are relatively unable to influence the fate of any one candidate relative to the others by giving them more financial support. As one Central European respondent noted in the IPU survey, "Once a woman is on a party list, or a party candidate, she has the same material and financial support as her male colleagues" (IPU 2000, p. 89). Instead, what matters is placement

\footnotetext{
${ }^{37}$ The effect of female elites in proportional representation systems is even stronger if Guyana is removed from the sample. A $10 \%$ increase in female party bureau members leads to a $7 \%$ increase in female candidates in that case. The effect of female party bureau members in plurality-majority systems remains the same, -.18 .
} 


\section{American Journal of Sociology}

on the party list. And, as previous quantitative and qualitative research has shown, women tend to be placed lower on party lists (e.g., Kunovich 2003). Our results suggest that while female leaders can articulate the need for female candidates, they are less able to place those candidates in winnable positions. As a West African IPU respondent complained, "Women actively participate in the same way as men, but they don't manage to move upwards, always holding subordinated positions in political organizations and on electoral lists" (IPU 2000, p. 60).

Contrast this to the situation of female leaders in plurality-majority systems. Once the battle for who will be a candidate is over, each party has the incentive to support their candidate fully, whether male or female. And, female party leaders are in a position to provide additional support to their female candidates in the form of campaign money or better institutional resources for campaigning. In the United States organizations such as Emily's List raise money and provide additional training and institutional support for female candidates in their bid for office. These types of organizations have also been crucial to women's success in several African nations (Tripp 2001). Female party leaders can tap into these external resources to help women gain a legislative seat once they are nominated as a candidate.

An important question remains: Why do we see these interaction effects for women in party bureau positions but not for women in leadership positions such as party chairperson or party spokesperson? The answer is likely because of critical mass (Dahlerup 1988; Staudt 1996; Jaquette 1997; Kanter 1977; but see Studlar and McAllister 2002). It is important to remember that, generally, women's representation in elite positions is low. ${ }^{38}$ When women are only a small part of the leadership, their impact is also likely to be small. IPU respondents from Central and West Africa, Southern Europe, and South America all commented that because

\footnotetext{
${ }^{38}$ Even before women had suffrage and the right to stand for national office, women played some roles in the success and failures of political parties (Ostrogorski 1902, chap. 6). But after gaining suffrage and the right to stand for office, women continued to be primarily relegated to informal roles within political parties. Women's level of involvement in party politics has been steadily increasing. By 1990, women comprised $40 \%-50 \%$ of party members in several Western European nations (Henig and Henig 2001). Despite these high levels of participation in the lower ranks, the proportion of women among party executives and key committee members is substantially lower (Norris and Lovenduski 1993). "So far, very few women are leaders of political organizations. Usually they simply join political parties created and led by men" (West African respondant; IPU 2000, p. 55). This occurs not just in countries where women are new to the political arena. As a female legislator from a Nordic country stated in the IPU's survey of female legislators, "We have the highest women's representation in the world $(43 \%)$ but men still dominate as party leaders and in the most 'heavy' positions" (2000, p. 19).
} 
women's participation in parties and party elites was minimal, female members were unable to change the party culture or increase support for female candidates (IPU 2000, pp. 59-61). When women make up only a small portion of the party, they are, according to an East African respondent, vulnerable: "The few who are determined to confront the male politicians within the party end up being called all sorts of namesinsolent, would-be men, etc.- - and they are often ignored and pushed to one side" (IPU 2000, p. 56). Active discrimination on the part of male leaders may also occur: a legislator from East Africa claims that "even though I am a member of the executive committee of the party I am often kept out of important decisions and even meetings" (IPU 2000, p. 20). ${ }^{39}$

With critical mass in mind, it is worth noting that the average percentage of women in leadership positions in parties is $10 \%$, while the average percentage in the party bureau is $17 \%$. More telling, the median percentage of women in party bureaus is $14 \%$ compared to only $5 \%$ women in leadership positions. Indeed, in $30 \%$ of the countries we examined, there are no women in leadership positions. On average, women in party bureaus may be better approaching levels that produce results: "The central committee of the RCD has included $21.3 \%$ women. The change is tangible. In meetings, when a woman speaks in favor of a proposal which concerns women, the applause is louder and more sustained, at least from her female colleagues. They can have a decisive influence during debates and on decisions. A significant percentage can sway a vote" (North African respondent; IPU 2000, p. 68). When women in leadership positions approach these numbers on a more regular basis, we may begin to see more positive results for women. ${ }^{40}$

${ }^{39}$ Further, without a critical mass of women for support, women may be unwilling to support other women (Sawer 2002). An IPU respondent from Southern Europe states "if . . . the number of women politicians is small as in the case of my country, politics may change women because, in order to survive politically, women may copy the men in their methods and behavior" (IPU 2000, p. 23). This statement echoes Lovenduski's (1993) warning that institutions can change women before women change institutions. Especially in highly visible positions, women may need to be cognizant of sanctions for being seen to act in the interests of women. Relating the experience of Labour MPs in Great Britain, Childs (2002, p. 151) explains, "The most common perception is that women who seek to act for women act only for women. This results in a tension between a woman MP's parliamentary career and acting for women. If an MP desires promotion, she cannot afford to be regarded as acting for women too often or too forcefully."

${ }^{40}$ It is important to note that some of the women interviewed by the IPU felt strongly that the quality of female leaders was as important as numbers: "Just one courageous woman can be a vehicle for profound change where $30 \%$ may be of little effect" (Pacific respondent; IPU 2000, p. 68). Still most of the respondents appeared to feel that vehicles to increase percentages, such as internal party quotas, could only produce positive benefits. 
American Journal of Sociology

CONCLUSION

In order for women to be elected to Parliament, the political parties have the responsibility of trusting in women, encouraging them, and putting them forward in constituencies where they can be certain of electoral success. (Central African respondent; IPU 2000, p. 97)

Despite advances in women's levels of education and participation in the paid economy over the last 20 years (Clark, Ramsbey, and Adler 1991; Jacobs 1996), women have made little significant progress with respect to their representation in national politics. In the United States, women account for $46 \%$ of the paid labor force and $55 \%$ of tertiary students (United Nations 2000). However, their representation in Congress and the Senate remains $13 \%$ and $14 \%$, respectively. The situation is similar in other nations. Currently 182 countries allow women to stand for office. Yet women make up fewer than $20 \%$ of elected representatives in the great majority of these countries (IPU 2004). Women's low rate of participation at the highest levels of politics remains an enduring problem in gender stratification (Paxton and Kunovich 2003).

In this article, we have attempted to expand our understanding of the problem of women's political representation by thinking of politics as a process with several important stages for women. First, women must be selected as candidates, and second, female candidates must be elected. In most countries, political parties are the primary means by which individuals are selected and supported in their bids for the public office. Thus, our primary focus is on women's inclusion in political parties and how that impacts both the selection and support of female candidates. We argue that features of political parties mediate and interact with countrylevel factors, such as a country's electoral system, in influencing women's political outcomes.

We find that women's inclusion in parties is important in helping women to become candidates and elected officials, but that the ways in which female elites can make a difference varies across electoral systems. Put briefly, female party leaders are able to increase numbers of female candidates in proportional representation systems. But female party leaders can help female candidates get elected in plurality-majority (nonPRPL) systems. This finding has important implications for the ways in which women can use their growing presence in leadership positions to the benefit of other women. Female leaders need to recognize the electoral constraints under which they operate and work to overcome those constraints. At the same time, female leaders can work to exploit the opportunities their electoral system may provide.

While the state or various parties may wish to redress historic ine- 
qualities by instituting quotas, we do not see an effect of quotas in this analysis. However, we believe that this finding is likely the result of the constraints of our data. With better measures of quotas, especially those accounting for quotas of different types, we expect that, like other studies, we would find positive impacts for women's political outcomes, at least under certain types of quotas. On a related note, we see that complacent parties do not feel pressure to field women-without marginal parties challenging the more complacent, established parties, women's representation as candidates is reduced.

Finally, we find evidence for the importance of ideological proxies, which corresponds to much previous research (e.g., Paxton 1997; Paxton and Kunovich 2003; Norris and Inglehart 2001). However, it is interesting that while we find ideology influences the gender composition of party elites in a country and the percentage of women candidates, we do not find that ideology influences how well women fare at the polls. This suggests that parties may be overly sensitive to the perceived liability of women as candidates, when in fact, women have equal success as candidates across all regions of the world.

Overall, our results stress the importance of parties for women's political representation. Even if parties do not actively discriminate against women, political parties are the gatekeepers that can limit women's access to national legislatures. Through the candidate selection process, political parties limit the choices available to voters. By differentially supporting candidates, parties also influence the election process. Since the percentage of female candidates largely determines the percentage of women elected, it is clear that parties must rise to the challenge by recruiting and supporting female candidates.

While forces outside an individual party's control, such as the electoral system under which it must operate, have an effect on women's representation as candidates and how well female candidates do at the polls, parties could do more to increase women's achieving elected office. First, our results indicate that parties should not assume that the electorate will not accept female candidates. Second, when the state acts to appoint women or other traditionally marginalized groups to the legislature, political parties should not assume this means they have no personal responsibility to increase their own selection of these groups as candidates. Finally, parties should remove any barriers to women's full participation as political elites. Without the internal barriers mentioned by the respondents in the IPU's survey of elected officials, women might be better able to translate their numbers in party bureaus or other positions of power into increased gains for women.

What role do female elites within parties play in changing or perpetuating female underrepresentation? Echoing Sanbonmatsu's (2002) con- 


\section{American Journal of Sociology}

clusions about women in the United States, we could say that there is no single path for women to elected office. Female leaders need to consider the constraints of their electoral system and plan strategies to increase women's representation as candidates and legislators accordingly. In PRPL systems, female elites should remember that stressing a balanced party list will not translate into more female legislators unless they also press for better list positions. The situation may be more difficult in plurality-majority systems. There, female party elites must fight the perception of electoral contests as zero-sum outcomes to ensure better representation of women as candidates. ${ }^{41}$

Our study demonstrated the utility of developing measures that allow cross-national researchers to investigate the entire process of women's inclusion in politics. However, our study remains limited by its focus on only one cross-section of elections. Longitudinal data would be better able to address how the positive impact of female party leaders and party bureau members might evolve over time as women's representation in these positions increases and their influence strengthens. Longitudinal analyses could also more rigorously test the propositions outlined here by examining changes in parties, leadership, and electoral rules on the proportion of women in office over time. Finally, longitudinal data would be able to test whether women's political fate is tied to the fate of certain political parties, and whether the ideological composition of the national legislature (percentage of seats held by socially liberal vs. conservative parties) influences women's electoral outcomes.

While the countries in our sample are representative of national leg-

${ }^{41}$ While the focus of this article is the number of women selected as political candidates, and how many of those are elected, we acknowledge that diversity among women selected and elected is also of paramount importance. It is likely that the women who run for, and are elected to, political office are not typical of women in their country. An important challenge facing female political leaders is the ability to represent the interest of a wide variety of women while maintaining good standing with constituents and party leaders. In fact, women's parliamentary caucuses have been formed in a substantial number of countries in order to provide an institutional structure within which representatives from competing parties can pool resources in order to focus on issues of concern for women and children. In a recent address, Edna Madzongwe, the Deputy Speaker of the Zimbabwe Parliament and head of the Women's Caucus, referenced this challenge faced by female representatives: "Women parliamentarians have a dual representative role in that, apart from representing constituencies, you also represent women who constitute $55 \%$ of our population. As such you should remain focused on the challenging task before you of representing the largest but marginalized group in our society. You are therefore expected to spearhead change in societal attitudes by virtue of your being in Parliament by ensuring that legislation passed by the House is gender sensitive" (see archive of speeches from public figures in Zimbabwe, http://www.kubatana.net). Even as women begin to comprise $30 \%$ of national legislatures, it may take considerably more time before women have the authority and resources to represent the diversity of interests among women. 
islatures worldwide, the range of variables we could consider was constrained by available data. For example, party ideology is an important variable, as theory and some research have demonstrated that left parties are more likely to field female candidates. But data, especially for nonWestern countries, are not currently available. Similarly, we would ideally have also considered women's presence in professional careers such as law, the strength of any feminist movement, and the percentage of voters who are women. It is critical that future research collect and include these variables in quantitative studies. ${ }^{42}$

Finally, it is important to remember that candidate nomination procedures vary cross-nationally in ways not considered here (Gallagher and Marsh 1988, p. 237). For example, in some countries like the United States, party leaders have much less influence in the candidate selection process. Candidate selection also depends on the level of centralization of decision making and the level of party bureaucracy (Matland 2002). Thus, researchers need to collect additional measures of the candidate selection process, such as party centralization and the institutionalization of rules, in order to further understand this process. Proportional representation systems are hypothesized to be beneficial for women for a variety of reasons, including larger district magnitudes and the publication of lists. Further research could consider which specific features of PRPL systems facilitate the ability of female party leaders to promote female candidates. For example, in closed-list systems, a voter cannot change the order of the list of candidates provided by the party. In an open-list system, voters can. Extrapolating from our results, among PRPL systems, female party elites should have more influence on the return of female candidates in open-list systems as they have more of a chance to influence voters by spending money or organizing list switching. As a South American IPU respondent explained, "I was the last person on the list, but a campaign helped me to be elected with preferential votes of more women voters" (IPU 2000, p. 89). ${ }^{43}$

Ultimately, this article demonstrates that the characteristics of parties mediate and interact with more general country-level factors in producing outcomes for women. The interaction we find here between electoral system and female party leaders provides a tantalizing glimpse of how we may ultimately understand the relationship between political structures at the national and party level in providing both opportunities and constraints for women to increase their numbers. While it is challenging to obtain the appropriate data to study this process cross-nationally, it is

${ }^{42}$ The IPU should be recognized for collecting party-level data for a range of countries. We hope that, in the future, such data sets will be less rare.

${ }^{43}$ Organized list-switching drives can backfire (Matland 2002). 
American Journal of Sociology

clear from these results that the candidate selection process needs to become part of the standard model. 


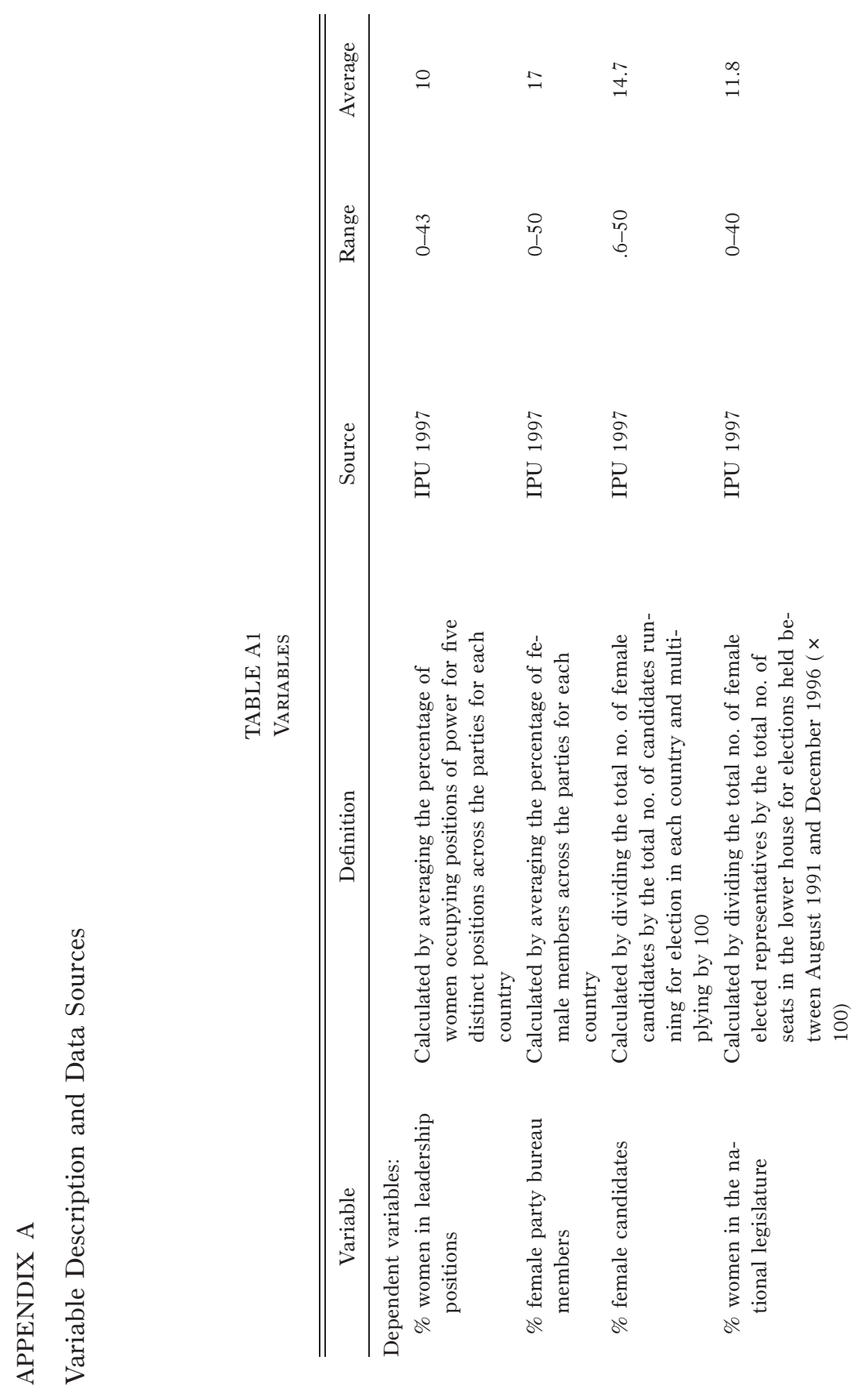




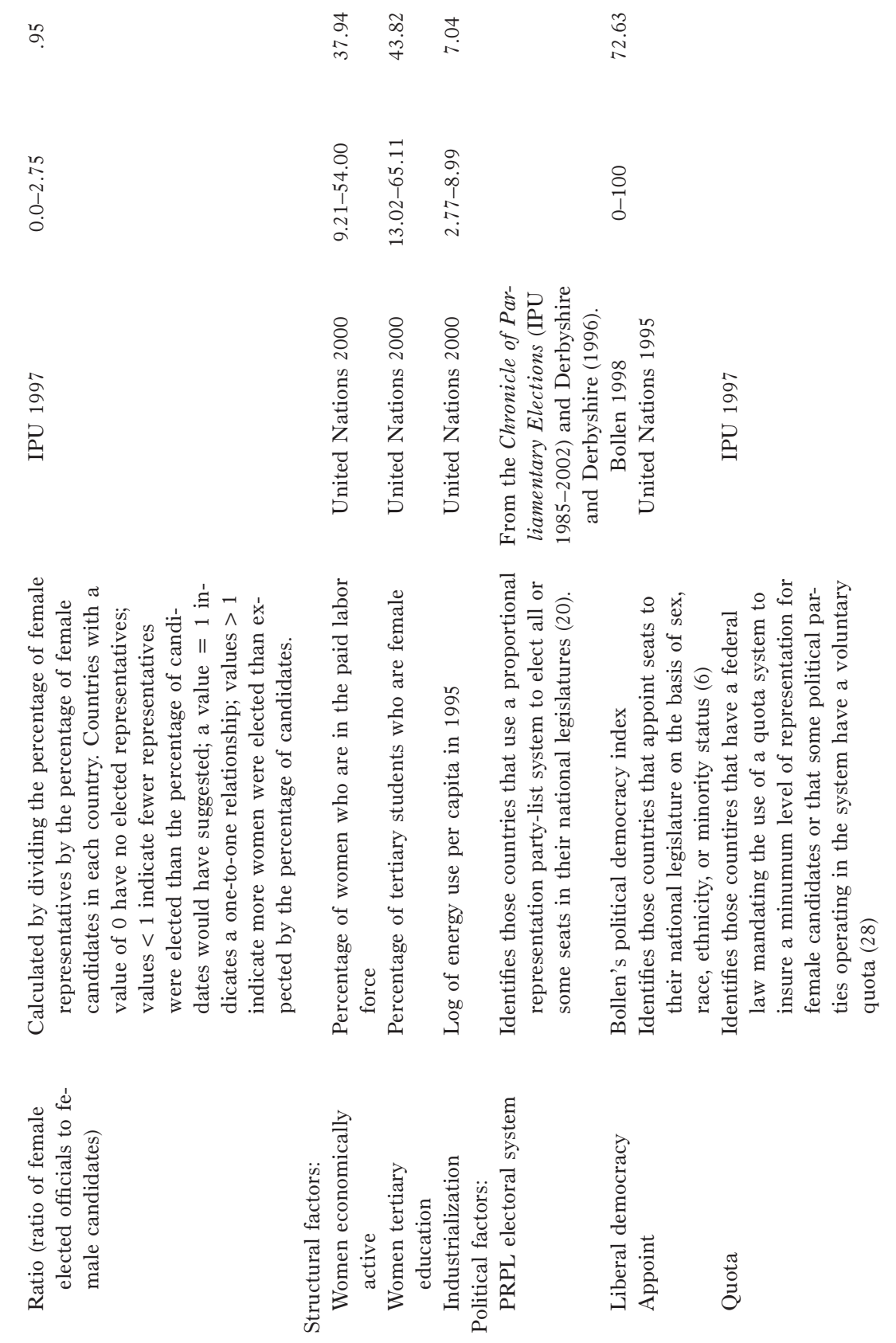




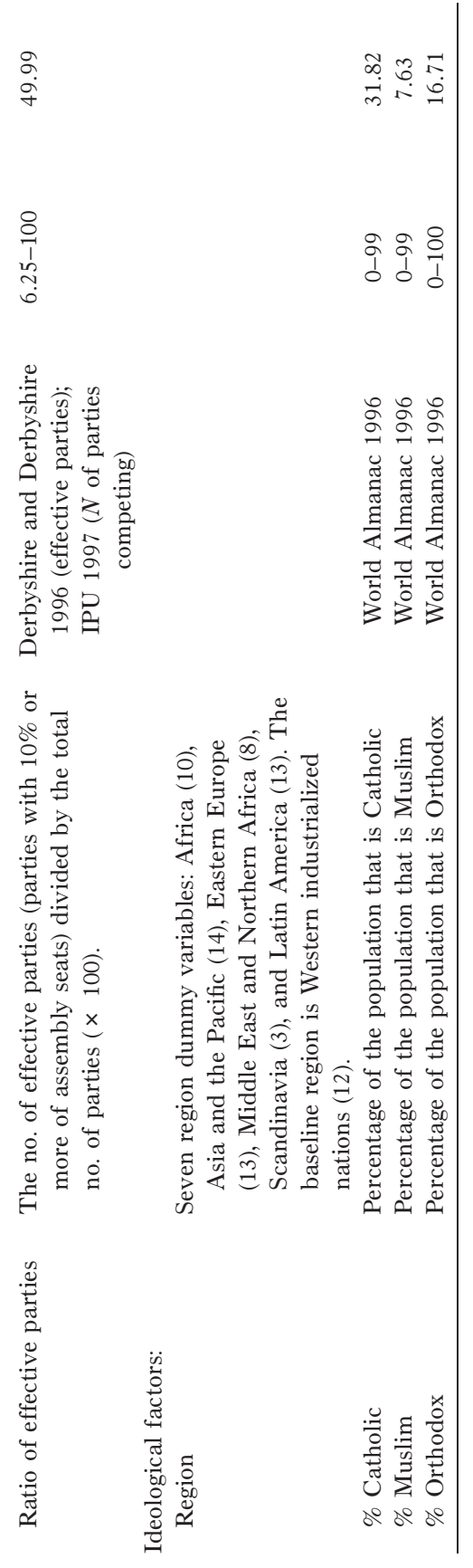




\section{American Journal of Sociology}

\section{REFERENCES}

Abukhalil, As'ad. 1997. "Change and Democratisation in the Arab World: The Role of Political Parties." Third World Quarterly 18 (1): 149-63.

Ahmed, Leila. 1992. Women and Gender in Islam. New Haven, Conn.: Yale University Press.

Al-Ahram On-line Weekly. 2000. "The New Equation." November 16.

Allison, Paul. 2002. Missing Data. Thousand Oaks, Calif.: Sage.

Arceneaux, Kevin. 2001. "The 'Gender Gap' in State Legislative Representation: New Data to Tackle an Old Question." Political Research Quarterly 54 (1): 143-60.

Associated Press. 2004. "Nobel Laureate Speaks Out for Women." March 8.

Avicenna. 1963. "The Book of Healing." In Medieval Political Philosophy, edited by Ralph Lernel and Muhsin Mahdi. New York: Free Press.

Beckwith, Karen. 1992. "Comparative Research and Electoral Systems: Lessons from France and Italy." Women and Politics 12 (1): 1-33.

Bille, Lars. 2001. "Democratizing a Democratic Procedure: Myth of Reality? Candidate Selection in Western European Parties, 1960-1990." Party Politics 7 (3): 363-80.

Bollen, Kenneth A. 1998. Cross-national Indicators of Liberal Democracy, 1950-1980. Codebook. University of North Carolina, Chapel Hill.

Bonevac, D W. B., and S. Phillips. 1992. Beyond the Western Tradition: Readings in Moral and Political Philosophy. Mountain View, Calif.: Mayfield.

Botman, Selma. 1999. Engendering Citizenship in Egypt. New York: Columbia University Press.

British Broadcasting Corporation. 2001. "Candidate Selection." Web news report, http: //news.bbc.co.uk. February 17.

Caldwell, John C. 1986. "Routes to Low Mortality in Poor Countries." Population and Development Review 12:171-220.

Caul, Miki. 1999. "Women's Representation in Parliament: The Role of Political Parties." Party Politics 5 (1): 79-98.

- 2001. "Political Parties and the Adoption of Candidate Gender Quotas: A Cross-National Analysis." Journal of Politics 63 (4): 1214-29.

Childs, Sarah. 2002. "Hitting the Target: Are Labour Women MPs 'Acting for' Women?" Parliamentary Affairs 55:143-53.

Clark, Roger, Thomas W. Ramsbey, and Emily S. Adler. 1991. "Culture, Gender, and Labor Force Participation: A Cross-National Study.” Gender and Society 5 (1): 47-66.

Commonwealth Secretariat. 1999. Women in Politics: Voices from the Commonwealth. London: Commonwealth Secretariat.

Connell, R. W. 1990. "The State, Gender, and Sexual Politics." Theory and Society 19: $507-44$.

Czudnowski, Moshe M. 1975. "Political Recruitment." Pp. 155-242 in Handbook of Political Science, vol. 2, Micropolitical Theory. Edited by Fred Greenstein and Nelson Polsby. Reading, Mass.: Addison-Wesley.

Dahlerup, Drude. 1988. "From a Small to Large Minority: Women in Scandinavian Politics." Scandinavian Political Studies 11:275-97.

—. 2002. "Using Quotas to Increase Women's Political Representation." Chap. 4 in Women in Parliament: Beyond Numbers. Stockholm: International IDEA.

Dahlerup, Drude, and Lenita Freidenvall. 2005. "Quotas as a 'Fast Track' to Equal Representation for Women: Why Scandinavia Is No Longer the Model." International Feminist Journal of Politics 7 (1): 104-23.

Derbyshire, J. D., and Ian Derbyshire. 1996. Political Systems of the World. New York: St. Martin's.

Duverger, Michel. 1955. The Political Role of Women. Paris: UNESCO.

Freedman, Jane. 2004. "Increasing Women's Political Representation: The Limits of Consitutional Reform." West European Politics 27 (1): 104-23. 
Gallagher, Michael, and Michael Marsh, eds. 1988. Candidate Selection in Comparative Perspective: The Secret Garden of Politics. London: Sage.

Giele, J. Z., and A. C. Smock, eds. 1977. Women, Roles, and Status in Eight Countries New York: Wiley.

Glaser, Kurt, and Stefan T. Possony. 1979. Victims of Politics: The State of Human Rights. New York: Columbia University Press.

Goetz, Anne-Marie, and Shireen Hassim. 2003. No Shortcuts to Power: African Women in Politics and Policy Making. London: Zed Books.

Heckscher, Grunnar. 1984. The Welfare State and Beyond: Success and Problems in Scandinavia. Minneapolis: University of Minnesota Press.

Hegel, Georg. 1977. "The Philosophy of Right." In History of Ideas on Women: A Source Book, edited by Rosemary Agonito. New York: G. P. Putnam.

Henig, Ruth, and Simon Henig. 2001. Women and Political Power: Europe since 1945. London: Routledge.

Hernes, Helga M. 1987. Welfare State and Women Power. Oslo: Norwegian University Press.

Howell, Jude. 2002. "Women's Political Participation in China: Struggling to Hold Up Half the Sky." Parliamentary Affairs 55:43-56.

Inglehart, Ronald, et al. 2000. World Values Surveys and European Values Surveys, 1981-1984, 1990-1993, 1995-1997 (MRDF). Ann Arbor, Mich.: Institute for Social Research (ICPSR).

IPU (Inter-Parliamentary Union). 1985-2002. Chronicle of Parliamentary Elections. Geneva: IPU Secretariat.

- 1995. Women in Parliaments, 1945-1995. Geneva: Inter-Parliamentary Union. . 1997. Men and Women in Politics: Democracy Still in the Making. Geneva: Inter-Parliamentary Union.

2000. Politics: Women's Insight. Geneva: Inter-Parliamentary Union.

2004. Women in National Parliaments Statistical Archive. Web page, accessed February.

Jacobs, Jerry A. 1996. "Gender Inequality and Higher Education." Annual Review of Sociology 22:153-85.

Jaquette, Jane S. 1997. "Women in Power: From Tokenism to Critical Mass." Foreign Policy 108:23-37.

Jejeebhoy, Shireen J., and Zeba A. Sathar. 2001. "Women's Autonomy in India and Pakistan: The Influence of Religion and Region ." Population and Development Review 27:687-712.

Jones, Mark P. 1998. "Gender Quotas, Electoral Laws, and the Election of Women: Lessons from the Argentine Provinces.” Comparative Political Studies 31 (1): 3-21.

Jones, Mark P., and Patricio Navia. 1999. "Assessing the Effectiveness of Gender Quotas in Open-List Proportional Representation Electoral Systems." Social Science Quarterly 80 (2): 341-56.

Kanter, Mim. 1977. "Some Effects of Proportions on Group Life: Skewed Sex Ratios and Responses to Token Women." American Journal of Sociology 82:965-90.

Karvonen, Lauri, and Per Selle. 1995. Women in Nordic Politics: Closing the Gap. Aldershot: Dartmouth.

Kelber, Mim. 1994. Women and Government: New Ways to Political Power. Westport, Conn.: Praeger.

Kenworthy, Lane, and Melissa Malami. 1999. "Gender Inequality in Political Representation: A Worldwide Comparative Analysis.” Social Forces 78 (1): 235-68.

Kohn, W. S. 1980. Women in National Legislatures: A Comparative Study of Six Countries. New York: Praeger.

Krook, Mona. 2003. "Not All Quotas Are Created Equal: Trajectories of Reform to Increase Women's Political Representativeness." Paper presented at the annual meeting of the European Consortium for Political Research, Edinburgh. 


\section{American Journal of Sociology}

. 2004a. "Gender Quotas as a Global Phenomenon: Actors and Strategies in
Quota Adoption." European Political Science 3 (3): 59-64. . 2004b. "Reforming Representation: The Diffusion of Candidate Gender Quotas Worldwide." Paper presented at the annual meeting of the International Studies Association, Montreal.

Kunovich, Sheri. 2003. "The Representation of Polish and Czech Women in National Politics." Comparative Politics 35:273-91.

Lovenduski, Joni. 1993. "Introduction: The Dynamics of Gender and Party." Pp. 1-15 in Gender and Party Politics, edited by Joni Lovenduski and Pippa Norris. London: Sage.

Lovenduski, Joni, and J. Hills. 1981. The Politics of the Second Electorate: Women and Public Participation. London: Routledge \& Kegan Paul.

Lovenduski, Joni, and Pippa Norris. 1993. Gender and Party Politics. London: Sage.

MacKinnon, Catherine. 1989. Toward a Feminist Theory of the State. Cambridge, Mass.: Harvard University Press.

Mateo Diez, Mercedes. 2002. "Are Women in Parliament Representing Women? From Descriptive to Substantive Representation . . . and Back Again?” Research report, University of Louvain.

Matland, Richard E. 1998. "Women's Representation in National Legislatures: Developed and Developing Countries." Legislative Studies Quarterly 23 (1) 109-25. . 2002. "Enhancing Women's Political Participation: Legislative Recruitment and Electoral Systems." Pp. 65-88 in Women in Parliament: Beyond Numbers, edited by Azza Karam. Stockholm: International IDEA.

Matland, Richard E., and Kathleen A. Montgomery, eds. 2003. Women's Access to Power in Post-Communist Europe. Oxford: Oxford University Press.

Matland, Richard E., and Donley T. Studlar. 1996. "The Contagion of Women Candidates in Single-Member District and Proportional Representation Electoral Systems: Canada and Norway." Journal of Politics 3:707-33.

McCammon, Holly J., Karen E. Campbell, Ellen M. Granberg, and Christine Mowery. 2001. "How Movements Win: Gendered Opportunity Structures and U.S. Women's Suffrage Movements, 1866-1919." American Sociological Review 66 (1): 49-70.

McDonagh, Eileen. 2002. "Political Citizenship and Democratization: The Gender Paradox." American Political Science Review 96 (3): 535-52.

Moore, Gwen, and Gene Shackman. 1996. "Gender and Authority: A Cross-National Study.” Social Science Quarterly 77:273-88.

Nechemias, Carol. 1994. "Democratization and Women's Access to Legislative Seats: The Soviet Cast, 1989-1991." Women and Politics 14 (3): 1-18.

Nizamu'l-Mulk Tusi. 1977. Studies in Muslim Political Thought and Administration, 4th ed. Edited by Harron K. Sherwani. Philadelphia: Porcupine.

Norris, Pippa. 1985. "Women's Legislative Participation in Western Europe." West European Politics 8:90-101.

—. 1993. "Conclusions: Comparing Legislative Recruitment." Pp. 309-30 in Gender and Party Politics, edited by Joni Lovenduski and Pippa Norris. London: Sage.

—. 1996. "Legislative Recruitment." Pp. 184-214 in Comparing Democracies: Elections and Voting in Global Perspective, edited by Joni Lovenduski and Pippa Norris. London: Sage.

- 1997. Passages to Power: Legislative Recruitment in Advanced Democracies. Cambridge: Cambridge University Press.

Norris, Pippa, and Ronald Inglehart. 2001. "Cultural Obstacles to Equal Representation." Journal of Democracy 12:126-40.

. 2003. "Islamic Culture and Democracy: Testing the 'Clash of Civilizations' Thesis." Pp. 5-34 in Human Values and Social Change: Findings from the Values Survey, edited by Ronald Inglehart. Leiden: Brill. 


\section{Pathways to Power}

Norris, Pippa, and Joni Lovenduski. 1993. "Gender and Party Politics in Britain.” Pp. 35-59 in Gender and Party Politics, edited by Joni Lovenduski and Pippa Norris. London: Sage.

Oakes, Ann, and Elizabeth Almquist. 1993. "Women in National Legislatures: A CrossNational Test of Macrostructural Theories." Population Research Policy and Review 12:71-81.

Ostrogorski, Moisei. 1902. Democracy and the Organization of Political Parties. New York: Macmillan.

Paxton, Pamela. 1997. "Women in National Legislatures: A Cross-National Analysis." Social Science Research 26:442-64.

Paxton, Pamela, and Sheri Kunovich. 2003. "Women's Political Representation: The Importance of Ideology." Social Forces 81 (5): 87-114.

Pesonen, Pertti. 1968. An Election in Finland: Party Activists and Voter Reactions. New Haven, Conn.: Yale University Press.

Phillips, Anne. 1991. Engendering Democracy. University Park: Pennsylvania State University Press.

Putnam, R. D. 1976. The Comparative Study of Political Elites. Englewood Cliffs, N.J.: Prentice Hall.

Rahat, Gideon, and Reuven Y. Hazan. 2001. "Candidate Selection Methods: An Analytical Framework." Party Politics 7 (3): 297-322.

Reynolds, Andrew. 1999. "Women in the Legislatures and Executives of the World Knocking at the Highest Glass Ceiling." World Politics 51:547-72.

Rule, Wilma. 1981. "Why Women Don't Run: The Critical Contextual Factors in Women's Legislative Recruitment." Western Political Quarterly 34:60-77.

1987. "Electoral Systems, Contextual Factors, and Women's Opportunity for Election to Parliament in Twenty-Three Democracies." Western Political Quarterly 40:477-98.

Rule, Wilma, and Joseph F. Zimmerman, eds. 1994. Electoral Systems in Comparative Perspective: Their Impact on Women and Minorities. Westport, Conn.: Greenwood.

Sanbonmatsu, Kira. 2002. "Political Parties and the Recruitment of Women to State Legislatures." Journal of Politics 64 (3): 791-809.

Sawer, Marian. 2002. "The Representation of Women in Australia: Meaning and MakeBelieve." Parlimentary Affairs 55:5-18.

Saxonberg, Steven. 2000. "Women in East European Parliaments." Journal of Democracy 11 (2): 145-58.

Schmidt, Gregory D., and Kyle L. Saunders. 2004. "Effective Quotas, Relative Party Magnitude and the Success of Female Candidates: Peruvian Municipal Elections in Comparative Perspective." Comparative Political Studies 37 (6): 704-34.

Staudt, Kathleen. 1996. "Women in Politics: Mexico in Global Perspective." Pp. 21-40 in Women in Politics: Mexico in Global Perspective, edited by Victoria E. Rodriguez. Boulder, Colo.: Westview.

Studlar, Donley T., and Ian McAllister. 2002. "Does a Critical Mass Exist? A Comparative Analysis of Women's Representation since 1950." European Journal of Political Research 41:233-53.

Tamale, Sylvia. 1999. When Hens Begin to Crow: Gender and Parliamentary Politics in Uganda. Boulder, Colo.: Westview.

Tremblay, M, and R Pelletier. 2001. "More Women Constituency Party Presidents: A Strategy for Increasing the Number of Women Candidates in Canada." Party Politics 7 (2): $157-90$.

Tripp, Aili M. 2001. "The New Political Activism in Africa." Journal of Democracy 12 (3): $141-55$.

United Nations. 1995. Human Development Report. New York: Oxford University Press. 


\section{American Journal of Sociology}

2000. The Women's Indicators and Statistics Database (WISTAT), ver. 4. New York: United Nations Publications.

von Hippel, P. T. 2003. "Normalization." Encyclopedia of Social Science Research Methods, edited by M. Lewis-Beck, A. Bryman, and T. F. Liao. Thousand Oaks, Calif.: Sage.

von Nieuwenhuijze, C. A. O. 1965. Social Stratification in the Middle East. The Hague: E. J. Brill.

Waylen, Georgina. 1994. "Women and Democratization: Conceptualizing Gender Relations in Transition Politics." World Politics 46 (3): 327-54.

Welch, Susan, and Donley T. Studlar. 1986. "British Public Opinion toward Women in Politics: A Comparative Perspective." Western Political Quarterly 39 (1): 138-54.

1996. "The Opportunity Structure for Women's Candidacies and Electability in Britain and the United States." Political Research Quarterly 49 (4): 861-74.

Williams, Melissa S. 1998. Voice, Trust, and Memory: Marginalized Groups and the Failings of Liberal Representation. Princeton, N.J.: Princeton University Press.

Wolchik, Sharon L. 1993. "Women and the Politics of Transition in Central and Eastern Europe." Pp. 29-47 in Democratic Reform and the Position of Women in Transitional Economies, edited by Valentine M. Moghadam. Oxford: Clarendon.

World Almanac. 1996. World Almanac and Book of Facts. New York: Press Publishing. World Bank. 1999. World Development Indicators. Washington, D.C.: World Bank.

Young, Lisa. 2000. Feminists and Party Politics. Ann Arbor: University of Michigan Press. 
Copyright of American Journal of Sociology is the property of University of Chicago Press. The copyright in an individual article may be maintained by the author in certain cases. Content may not be copied or emailed to multiple sites or posted to a listserv without the copyright holder's express written permission. However, users may print, download, or email articles for individual use. 